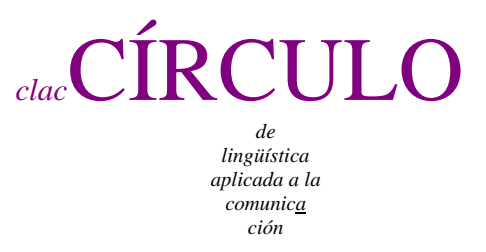

$67 / 2016$

\title{
INTERPRETACIÓN Y TIPOLOGÍA DEL PRONOMBRE INDEFINIDO UNO A PARTIR DE TRES GÉNEROS DISCURSIVOS
}

\author{
Marie Rasson \\ Université Catholique de Louvain \\ Fonds de la Recherche Scientifique - F.R.S.- FNRS \\ marie rasson en uclouvain be
}

Resumen

Este estudio trata el pronombre indefinido español uno. Tras un análisis profundizado sistemático de ocurrencias en lenguaje auténtico, constatamos que su interpretación varía en función del contexto lingüístico. Por lo tanto, examinamos qué elementos del contexto - nos centramos en el contexto más amplio que la oración - influyen en su interpretación y desarrollamos una tipología del pronombre indefinido en cuanto a su interpretación. El pronombre puede interpretarse como completamente genérico o como específico (refiriendo al hablante, al interlocutor o a una tercera persona). Su interpretación puede situarse también en una posición intermediaria entre estos extremos interpretativos.

Rasson, Marie. 2016.

Interpretación y tipología del pronombre indefinido uno a partir de tres géneros discursivos.

Círculo de Lingüística Aplicada a la Comunicación 67, 227-272.

http://www.ucm.es/info/circulo/no67/rasson.pdf

http://revistas.ucm.es/index.php/CLAC

http://dx.doi.org/10.5209/CLAC.53484

(C) 2016 Marie Rasson.

Círculo de Lingüística Aplicada a la Comunicación (clac)

Universidad Complutense de Madrid. ISSN 1576-4737. http://www.ucm.es/info/circulo 
Además, comparamos el uso en varios géneros discursivos - conversaciones espontáneas, redacciones académicas y un foro de la web - que se distinguen por la presencia o ausencia de interactividad y su menor/mayor subjetividad/intersubjetividad. De esta comparación, se desprende que el uso del pronombre depende de estas características.

Palabras clave: uno, intersubjetividad, estudio de corpus, género discursivo

\section{Abstract}

This study investigates the Spanish indefinite pronoun uno (“one”). After a detailed analysis of its occurrences in authentic language, we find that its interpretation varies depending on the linguistic context. Therefore, we examine which elements of the context - we focus on the broader context, beyond the sentence - have an impact on its interpretation and develop a typology of the indefinite pronoun as to its interpretation. The pronoun may be interpreted as completely generic or specific (referring to the speaker, the listener or a third person). Its interpretation can also be located in an intermediate position between these interpretive extremes.

In addition, we compare its use in various discursive genres - spontaneous conversations, academic essays and web forum - which are distinguished by the presence or absence of interactivity and of more or less subjectivity / intersubjectivity. The comparison shows that pronoun use depends on these characteristics.

Key words: uno (“one”), intersubjectivity, corpus study, discursive genre

Índice

1. Introducción 230

2. Estado de la cuestión 231

2.1. Uno como proceso generalizador 231

2.2. Influencia del contexto 232

2.3. Diferenciación de varios tipos de uno 232

3. Conceptos teóricos, hipótesis y metodología 237 
3.1. Conceptos importantes para las hipótesis y la metodología 237

3.2. Hipótesis 238

\subsection{Metodología 239}

4. Factores que influyen en la interpretación del pronombre 241

4.1. Factores que favorecen una reducción de la referencia 242

4.2. Factores que favorecen una lectura genérica de uno 244

5. Propuesta de tipología 245

5.1. Tipología general 246

5.1.1a. Tipo genérico 247

5.1.1b. Tipo genérico reducido 248

5.1.2a. Tipo centrado generalizado en el emisor 249

5.1.2b. Tipo centrado generalizado en el receptor 251

5.1.2c. Tipo centrado generalizado en una tercera persona 252

5.1.3a. Tipo específico - el emisor 254

5.1.3b. Tipo específico - el receptor y tipo específico - una tercera persona 254

5.1.4. Tipo ambiguo (referencial) 255

5.2. Posiciones intermediarias en el continuo 257

5.2.1. Tipo intermediario “centrado generalizado en el emisor y el receptor” (2ab) 258

5.2.2. Lectura intermediaria entre genérica y centrada generalizada en el receptor $(1 a-2 b) 260$

6. Estudio cuantitativo 261

6.1. Frecuencia del pronombre uno en tres géneros discursivos 261

6.2. Estudio cuantitativo de la tipología en los géneros estudiados 262

6.3. Análisis cuantitativo de los factores que influyen en la interpretación de uno en los géneros estudiados 264 


\section{Conclusión 266}

Corpus 268

Referencias bibliográficas 268

\section{Introducción}

En este artículo, se quiere mostrar que el pronombre indefinido uno en su uso genérico tiene interpretaciones distintas en función del contexto en que se encuentra. Además, pretendemos mostrar el impacto de varios factores lingüísticos en la interpretación del pronombre. Empezamos por un estado de la cuestión sobre el tema (2. Estado de la cuestión) ${ }^{1}$. Seguimos con algunos elementos teóricos importantes para las hipótesis y la metodología (3.1. Conceptos importantes), el planteamiento de las hipótesis (3.2. Hipótesis) y las cuestiones metodológicas (3.3. Metodología).

A partir de un análisis cualitativo detallado de corpus, presentamos una serie de factores del contexto lingüístico que influyen en la lectura del pronombre. Nos centramos en factores a nivel del contexto más amplio que la oración porque al contrario de factores del nivel proposicional o verbal (Bidot Martínez, 2008: 76-82), casi no han sido tratados en la literatura como elementos que influyen en la interpretación de uno. Distinguimos por una parte los factores que favorecen una interpretación genérica de uno y por otra parte los factores que favorecen una lectura específica (4. Factores que influyen en la interpretación del pronombre). Estos factores nos permitieron extraer una tipología de las interpretaciones del pronombre, que ilustramos con ejemplos (5. Propuesta de tipología). En el apartado 5.2. Posiciones intermediarias en el continuo, discutimos las ocurrencias de uno que se sitúan en posiciones intermediarias de nuestra tipología.

\footnotetext{
1 Agradezco a Barbara De Cock, Bettina Kluge, Liesbeth Degand y Magali Paquot sus valiosos comentarios y consejos sobre la redacción de este artículo.

Este estudio se ha desarrollado dentro del marco del proyecto "La comunicación imprecisa: mecanismos de interpretación y funcionamiento discursivo del pronombre indefinido español uno", financiado por los Fonds Spéciaux de Recherche de la Université Catholique de Louvain y por el Fonds de la Recherche Scientifique - F.R.S.- FNRS.
} 
Posteriormente, presentamos nuestro estudio de corpus basado en tres géneros discursivos/tipos de textos diferentes en varios puntos: conversaciones informales espontáneas, redacciones académicas de estudiantes, y un foro de preguntas y respuestas Yahoo. En primer lugar, comparamos la frecuencia de uno de manera general en cada género estudiado (6.1. Frecuencia del pronombre uno en tres géneros discursivos). En segundo lugar, profundizamos el uso de los distintos tipos de uno en los géneros estudiados (6.2. Estudio cuantitativo de la tipología en los géneros estudiados). En tercer lugar, comparamos los factores que influyen en la interpretación de uno en estos géneros discursivos (6.3. Análisis cuantitativo de los factores que influyen en la interpretación de "uno” en los géneros estudiados).

\section{Estado de la cuestión}

Presentamos primero los trabajos realizados sobre el pronombre indefinido uno. En la literatura, se han propuesto definiciones diferentes de uno indefinido. Se destacan los enfoques siguientes:

\subsection{Uno como proceso generalizador}

De manera general, todos los autores que se interesaron en la cuestión del pronombre uno indefinido concuerdan en decir que el pronombre indefinido uno generaliza la referencia, y que siempre refiere a un humano (Schroten, 1972: 19; Carrasco, 1980; Ridruejo, 1981; Gómez Torrego, 1994: 14-16; Haverkate, 1985: 13; DeMello, 2000: 371; Real Academia Española, 2009: 1132, 1163). Luego, la mayoría de los autores también precisan que el emisor siempre se incluye en esta referencia (Schroten, 1972: 19; Carrasco, 1980; Hollaender Jensen, 2002: 135-136; Flores-Ferrán, 2009: 1811; González Vergara y Hugo Rojas, 2012). En algunas gramáticas, en cambio, no se establece la distinción entre diferentes referencias del pronombre. Son todas consideradas como generalizadoras y encubridoras del “yo” (Schroten, 1972: 19; 2011: 170-175). El pronombre se describe entonces como una entidad con un solo significado. 


\subsection{Influencia del contexto}

Algunos autores precisan que la interpretación del pronombre indefinido puede variar en función del contexto (Gómez Torrego, 1994: 14-16; Carrasco, 1980: 163), sin detallar más el tipo de contexto que influye y las implicaciones en la interpretación del pronombre. Otros autores detallan más en qué medida el contexto influye en la interpretación del pronombre uno. Así, Lavandera indica que, si bien el carácter indefinido de este pronombre se refleja en su morfología, la referencia a la primera, segunda o tercera persona se observa en "algunas emisiones previas o posteriores" (1984: 107-108). La referencia a la primera persona se señala entonces mediante el pronombre yo u otra indicación de primera persona (por ejemplo la inflexión verbal de primera persona o el pronombre posesivo $\mathrm{mi}$ ). Por lo tanto, cuando el contexto refiere a la persona que habla/escribe en relación con uno, uno podría ser reemplazado por “cualquiera y yo también” o “yo, como cualquier otra persona” (1984: 107-108). Pozas Loyo (2010: 279) menciona igualmente, aunque de manera breve, que el pronombre indefinido se encuentra a menudo en correferencia con elementos de primera persona. Lavandera (1984: 108) señala además que, en cambio, si el contexto lingüístico "no incluye referencia personal, el pronombre sólo significa “indefinido””.

\subsection{Diferenciación de varios tipos de uno}

Ciertos investigadores reconocen que existen distintos tipos de uno indefinido y explicitan estas variaciones con mayor o menor detalle. A continuación, resumimos las principales categorizaciones propuestas en la literatura. Una síntesis de los puntos más destacables puede encontrarse al final de esta sección.

Bello y Cuervo (1964: 285) precisan que el pronombre indefinido uno suele sustituir el yo y que el referente es desde luego la primera persona del singular. El pronombre uno permite así enfatizarla.

Flores-Ferrán (2009: 1811), aunque sólo estudia el pronombre uno en los contextos \{+ específicos\} en posición sintáctica de sujeto a saber cuando el referente es el hablante y que este corresponde al yo (desde luego, no es genérico) especifica que existen varias interpretaciones posibles del pronombre. Habla de cuatro referentes posibles en posición 
de sujeto con distintos grados de especificidad y precisa que uno puede desempeñar varias funciones discursivas. Da algunos ejemplos pero no los detalla y no especifica a qué tipo corresponden (2009: 1811). Asimismo, indica que un estudio detallado de este pronombre y de su contexto lingüístico todavía es necesario. Menciona sin embargo que el referente puede ser exofórico, que puede ser un colectivo que no incluye al emisor o al receptor (2009: 1811). Luego, también puede incluir al hablante, al oyente inmediato o a cualquier otra persona. El contexto permite determinar su interpretación. No obstante, la información predicada de uno se puede interpretar como refiriéndose al interés personal del hablante y del oyente (2009: 1811).

Gelabert-Desnoyer (2008: 412-413) también propone una clasificación de cuatro tipos a partir de lo más general hacia lo más específico, dentro del espectro semántico, que elaboró a partir de un corpus de discurso de políticos. Distingue los tipos siguientes:

a) Omnipersonal: la referencia puede ser cualquiera y puede incluir al hablante.

b) Auto-referencial (“self-referential”): la referencia es exclusivamente al hablante (se deduce a partir del contexto lingüístico y extralingüístico).

c) Auto-referencial experiencial: Se relaciona íntimamente con el hablante, aunque con un grado menor, lo que permite una apertura de referencia hacia otros.

d) Otros-referencial: la referencia corresponde exclusivamente al interlocutor.

En los corpus utilizados para nuestro estudio, en cambio, encontramos ejemplos que no caben en estas categorías (véase 5. Propuesta de tipología), a lo mejor porque algunos usos no se encontraban ejemplificados en el corpus utilizado por Gelabert-Desnoyer.

Si bien los autores anteriormente expuestos presentan una clasificación de cuatro tipos, Rodríguez Alfano divide las interpretaciones posibles en tres tipos principales, en el marco de un estudio de entrevistas mexicanas de los años 1985-1986. Estos corresponden a una función expresiva (si se refiere al emisor) o apelativa (si se refiere al interlocutor):

1) el uno canónico, donde uno refiere a “yo”,

2) el uno exclusivo, donde designa al "yo" como prototipo de una clase de sujetos al que no pertenece el interlocutor y 
3) el uno inclusivo, que hace referencia al "yo" o al "tú", como prototipo de una clase de individuos a la que ambos (interlocutor y hablante) pertenecen.

La autora habla también de casos ambiguos donde no queda claro a qué grupo de individuos remite el pronombre, pero precisa que estos casos no aparecen frecuentemente (2004: 198-199). Su tipología varía de la tipología de cuatro tipos de Gelabert-Desnoyer porque no cuenta una categoría “otros-referencial”, que excluye al hablante. Además, Gelabert-Denoyer no distingue la exclusión o inclusión del interlocutor. Él categoriza más bien un tipo genérico que refiere a cualquiera, que no se encuentra en la tipología de Rodriguez Alfano.

González Vergara y Hugo Rojas (2012: 647-650), por una parte, y Hollaender Jensen (2002: 127), por otra parte, distinguen dos tipos de uno. Un primer tipo, común a ambas propuestas, es el uno que corresponde al “yo”. Después, González Vergara y Hugo Rojas disciernen un tipo evidencial, con “fuente de información” personal pero acceso a la información de forma universal: con este uso, uno permite al hablante de expresarse a partir de sus propias experiencias o creencias pero cualquiera podría estar de acuerdo con él (2012: 647-650). Hollaender Jensen, en cambio, destaca como segundo tipo un referente genérico, que define como "una colectividad equivalente a todo el mundo" (2002: 127). Según Hollaender Jensen, en el caso de uno como "yo” encubierto, el proceso siguiente tendría lugar: primero se generaliza y luego, una segunda etapa operaría una restricción contextual (2002: 128). En el segundo caso, el sentido genérico se observa pues cuando la referencia es más amplia y que no se ve tan claramente que se trata de uno de los participantes del evento de comunicación, aunque los participantes también forman parte de este grupo de referencia de humanos (2002: 130).

Ridruejo, por otra parte, no da una clasificación clara de tipos de uno pero podemos reconocer en su análisis por lo menos dos tipos: un uso de uno que refiere a la primera persona del singular y un uso que refiere a un grupo. El uso de uno como encubridor del “yo" sería un uso propio a un lenguaje de entorno popular. Sin embargo, precisa que este uso sería una especialización de su uso generalizador: serviría para dar a la oración un carácter general, aunque el hablante alude a sí mismo (1981: 78-79). Las reducciones de generalización hacia otro referente se deben a los componentes pragmáticos/ a los elementos designados en la realidad. Estos elementos contextuales pueden reducir la referencia a un grupo (y la reducción puede ser tan fuerte que se restringe al hablante) 
(1981: 80-81). La reducción de la referencia y los factores que la causan están tratados en este artículo (véase 4. Factores que influyen en la interpretación del pronombre y 5. Propuesta de tipología). La Real Academia Española distingue también dos interpretaciones distintas sin clasificarlas: la interpretación genérica y la que refiere al hablante (2009: 1163). De forma más general, la RAE estipula que el indefinido uno se usaría con grupos nominales genéricos que pueden aludir a cualquier individuo. "Las predicaciones en las que concurren expresan a menudo vivencias, ideas y sentimientos del hablante que se suponen extrapolables a los demás. Unas veces se presentan generalizaciones que el hablante aplica a sí mismo, sugiriendo que pueden extenderse a otros. [...] En muchas ocasiones, en cambio, la atribución que el hablante hace recae principalmente sobre el mismo.” (Real Academia Española, 2009: 1132)

Esta oposición entre una interpretación genérica y una interpretación personal aparece también en Lavandera (1984: 107). Habla de un significado indefinido y de personalización del pronombre uno (para más detalles, véase el apartado “influencia del contexto”).

De Cock (en prensa) muestra la relación frecuente entre el pronombre uno indefinido y el hablante. Al lado de esto, ejemplifica un uso de exclusión del hablante en la referencia de uno, donde el hablante mediante el pronombre muestra solidaridad con el receptor, con un efecto intersubjetivo. Esta lectura se hace gracias al contexto lingüístico más amplio.

Sintetizando, constatamos que todos los autores tratados en este apartado distinguen el tipo de uno que hace referencia al “yo”. Después, se distingue con más o menos detalle y precisión la categoría de uno genérico (a veces llamado 'generalizador', ‘indefinido’), que a veces se describe como prototipo de una clase, o marcador de evidencialidad. Algunos pocos autores describen tipos adicionales, p.e. uno específico, que refiere al interlocutor, o de referencia intermediaria, entre específico y genérico. Se habla raramente de casos con referencia ambigua. Asimismo, algunos investigadores mencionan la influencia del contexto lingüístico y/o extralingüístico en la interpretación del pronombre, pero de forma escasamente detallada. Ciertos autores relacionan las distintas categorías del pronombre con una función apelativa o con un efecto intersubjetivo, o bien con una función expresiva. 
Se observan, pues, en la literatura desacuerdo y descripciones en ciertos aspectos imprecisas. Además, el estudio cualitativo profundizado de ejemplos encontrados en varios géneros discursivos no siempre corresponde a los tipos descritos en la literatura. Por esos motivos, proponemos una nueva tipología desarrollada en el apartado 5. Propuesta de tipología.

A continuación, mencionamos algunos factores que influyen en el carácter genérico de las estructuras impersonales en español. Varios autores mostraron que ciertos elementos procedentes en mayor parte del nivel de la oración o del verbo influyen en la genericidad de las estrategias impersonales (Ridruejo, 1981, Fernández Soriano y Táboas Baylín, 1990: 1732-1737, Bidot Martínez, 2008: 76-82). Se trata del aspecto verbal, del tiempo verbal, de la presencia de verbos modales, del tipo de verbo (si es pronominal o no pronominal) y de la presencia de una oración condicional lógica. Dado que estos factores ya han sido tratados en varios estudios, nos limitaremos en este artículo a los factores que proceden del contexto más amplio que la oración, todavía poco estudiados.

Presentamos finalmente algunos estudios realizados sobre otras estrategias impersonales, en los que nos apoyamos para la elaboración de nuestra tipología (5. Propuesta de tipología).

Siewierska (2011) propone una categorización donde encontramos la distinción general entre genérico y específico, aplicada a todos los “man” impersonales (man-imp) y los impersonales de $3^{\mathrm{a}}$ persona del plural (3pl-imp).

Coussé y van de Auwera (2012) presentan igualmente una tipología para los man-imp, que retomaron de Givón (1984) y que se concibe como un continuo desde genérico hasta definido. Además de los tipos humano genérico y definido, distinguen los tipos “indefinido no referencial” e “indefinido referencial”. El uso indefinido no referencial corresponde a la referencia donde se puede delimitar un subgrupo de humanos, gracias al contexto. Sin embargo, este grupo no se puede identificar con precisión a partir del contexto. El tipo indefinido referencial mantiene vaga la identidad del referente. Los autores destacan la similitud entre esta función y la de la voz pasiva. Este tipo es parecido al tipo “vago” de Siewierska y Papastathi (2011) en su tipología de la tercera 
persona del plural impersonal - no se encuentran en este caso indicios para deducir quién es el referente.

Las tipologías presentadas inspiraron la tipología que proponemos de uno indefinido (véase 5. Propuesta de tipología). Sin embargo, distinguimos con más detalle los distintos tipos basados en la referencia del pronombre.

Van der Auwera, Gast y Vanderbiesen (2012: 7-8) desarrollaron un mapa semántico para los pronombres impersonales y distinguen para la definición de las categorías por una parte características de la situación (state of affairs) y por otra parte características del participante humano a quien refiere el pronombre. Sin embargo, no nos basamos en este mapa porque las distinciones dentro de la referencia no nos parecen suficientemente matizadas para el análisis del pronombre uno, que cobra un espectro largo de referencias posibles (véase 5. Propuesta de tipología).

\section{Conceptos teóricos, hipótesis y metodología}

\subsection{Conceptos importantes para las hipótesis y la metodología}

A continuación, presentamos conceptos importantes para nuestra metodología y nuestro análisis. Son a la base de nuestra segunda hipótesis (3.2. Hipótesis). Nos basamos en la definición de subjetividad de Benveniste (1966: 259-260) de ”De la subjectivité dans le langage”. Define el concepto de subjetividad de la manera siguiente: « La subjectivité dont nous traitons ici est la capacité du locuteur de se poser comme « sujet ». (...) Est « ego » qui dit « ego ». Nous trouvons là le fondement de la “subjectivité”, qui se détermine par le statut linguistique de la « personne ». » ${ }^{2}$ El hombre se constituye como « sujeto » en el lenguaje y por el lenguaje, porque sólo el lenguaje fundamenta, en la realidad del ente, el concepto de “ego”. Allí encontramos el estatuto lingüístico de la persona. Según Benveniste, el lenguaje es fuertemente marcado por la expresión de la

\footnotetext{
2 'La subjetividad de la que tratamos aquí es la capacidad del locutor de posicionarse como sujeto (...). Es “ego” quien dice “ego”. Encontramos allí el fundamento de la subjetividad, que se determina por el estatus lingüístico de "persona”.'
} 
subjetividad (1966: 260-261) y las primeras y más evidentes huellas de la subjetividad, en el lenguaje, son los pronombres personales (1966: 262). Consideramos desde luego marca de subjetividad, los elementos que refieren directamente al emisor o que están estrechamente relacionados con estos elementos.

La definición de intersubjetividad utilizada en este estudio viene de Traugott (2003: 128) y es basada a su vez en Benveniste (1966) y Lyons (1982): “intersubjectivity is the explicit expression of the SP/W's [speaker's/writer's] attention to the 'self' of addressee/reader in both an epistemic sense (paying attention to their presumed attitudes to the content of what is said), and in a more social sense (paying attention to their

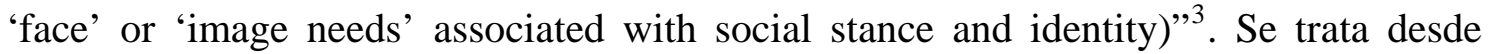
luego de rasgos explícitos de la atención que el emisor presta al receptor.

\subsection{Hipótesis}

En este artículo, comprobamos dos hipótesis. La primera es que la interpretación del pronombre indefinido uno depende del contexto lingüístico - no es únicamente inherente a la forma, como lo dejan entender algunos gramáticos (Schroten, 1972: 19; Martínez, 1989: 59-61). Varios factores del contexto a nivel amplio tendrían impacto en la interpretación del pronombre uno. Algunos autores, al contrario, mencionan la influencia del contexto en la interpretación de uno pero no profundizan la cuestión (véase 2. Estado de la cuestión).

La segunda es que el uso más o menos frecuente de este pronombre indefinido depende no sólo del registro, sino también de la importancia de la subjetividad y/o intersubjetividad en el género discursivo (De Cock, en prensa) y del carácter interaccional. El pronombre indefinido uno en varios casos sería usado para demostrar solidaridad o empatía con el receptor (intersubjetividad) y/o para proteger su propia imagen.

\footnotetext{
3 'La intersubjetividad es la expresión explícita de atención del hablante/escritor hacia el “yo” del destinatario/lector, tanto en un sentido epistémico (prestar atención a sus actitudes supuestas hacia el contenido de lo que se dice), como un sentido más social (prestar atención a su "imagen” o sus “necesidades de imagen” asociadas con la postura social y la identidad).'
} 
Los conceptos de subjetividad e interactividad han sido relacionados con el género discursivo. Los géneros escritos presentarían un grado menor de subjetividad (Dahl, 2000). Al contrario, en los géneros con interactividad, la subjetividad tendría un papel más importante (Scheibman, 2002; De Cock, 2014 (a): 249-250; 278-279). Desde luego, nuestra hipótesis es que la presencia de subjetividad/ intersubjetividad juega un papel en el funcionamiento de uno.

\subsection{Metodología}

Para verificar la primera hipótesis, es decir, si la interpretación del pronombre uno depende del contexto lingüístico, estudiamos de manera detallada y sistemática el pronombre en contexto en un corpus formado por textos de géneros distintos, cuya selección se detallará más adelante (conversaciones espontáneas e informales (CORLEC), 240759 palabras, redacciones académicas escritas por estudiantes (CLAE), 243900 palabras, y preguntas y respuestas del foro web Yahoo (YCCQA), 667847 palabras). Examinamos cómo se interpreta cada ocurrencia encontrada (véase apartados 6. y 7.) y profundizamos este aspecto examinando algunos elementos del contexto lingüístico que influyen en la interpretación del pronombre. Este análisis cualitativo detallado desemboca en una tipología basada en las distintas interpretaciones posibles del pronombre, que encontramos en nuestra investigación (véase 5. Propuesta de tipología).

Para verificar la segunda hipótesis, examinamos la presencia/ausencia del pronombre en géneros que se sitúan en los polos opuestos en el continuo "mayor subjetividad/intersubjetividad” - “menor subjetividad/intersubjetividad”. Además, los géneros se oponen en cuanto al carácter interaccional y no interaccional.

En primer lugar, estudiamos el corpus CLAE, compuesto de redacciones académicas escritas por estudiantes mexicanos en el marco de sus estudios universitarios. Agrupa ensayos, resúmenes, preguntas y respuestas, reseñas y reportes. Presenta las características "menor subjetividad/intersubjetividad” y “no interaccional”. La ausencia/menor presencia de subjetividad en textos académico fue tratada por Biber en Variation across speech and writing (1988: 108), aunque usa los términos de "personal affect” (afecto personal). 
En segundo lugar, estudiamos conversaciones informales espontáneas centropeninsulares, procedentes del corpus CORLEC, Corpus del Español centropeninsular. Biber señala el alto nivel de interactividad y de afecto personal, en otras palabras de subjetividad, en las conversaciones cara a cara (1988: 131). Koch y Oesterreicher las relacionan con "lenguaje de la proximidad”, que corresponde a un polo oral, caracterizado por las combinaciones de los factores “diálogo”, “cambio de interlocutores libre”, "familiaridad de los interlocutores”, “interacción face-to-face”, “libre desarrollo de los temas”, “no público”, “espontaneidad”, “fuerte participación”, "fuerte enredo" etc.. Este polo se opone al polo escrito, que corresponde al "lenguaje de la distancia” (1985: 18-23).

Por fin, analizamos un corpus de procedencia digital, preguntas y respuestas del foro web Yahoo, Yahoo-based Contrastive Corpus of Questions and Answers (YCCQA), que mezcla algunos rasgos de la escritura y de la oralidad (Placencia, 2012: 289). Dado que se trata de preguntas y respuestas, presenta también la característica interaccional. En realidad, se sitúa a la frontera de la interacción dialogal y la publicación de tipo periodístico (Placencia, 2012: 286). La interacción pregunta-respuesta crea dialogicidad, y la comunicación de masa resulta del hecho de que la respuesta, además de estar obviamente dirigida a la persona que hizo la pregunta, es de cierta forma destinada al gran público por su publicación en la web (Locher, 2013: 344). Además, se trata de un tipo de comunicación informal y directa, con una relación igualitaria entre participantes (Placencia, 2012: 288-289), lo que deja suponer mayor presencia de subjetividad/intersubjetividad. Luego, se puede suponer también un alto nivel de intersubjetividad en este género porque típicamente consiste en consejos. El acto de aconsejar, por la implicación de las imágenes (faces) de los participantes, favorecería la intersubjetividad.

Los tres corpus analizados contienen varios casos de lenguaje no normativo, sobre todo las conversaciones informales y el foro, visto que se trata de lengua espontánea. Los ejemplos presentados en este artículo son fidedignos y pueden, como tal, contener usos no normativos.

Nuestro análisis es en primer lugar cualitativo (4. Factores que influyen en la interpretación del pronombre, 5. Propuesta de tipología, 5.2. Posiciones intermediarias en el continuo). En segundo lugar, proponemos un análisis cuantitativo de uno en los 
distintos géneros discursivos (6. Estudio cuantitativo, 6.1. Frecuencia del pronombre uno en tres géneros discursivos, 6.2. Estudio cuantitativo de la tipología en los géneros estudiados, 6.3. Análisis cuantitativo de los factores que influyen en la interpretación de “uno” en los géneros estudiados).

4. Factores que influyen en la interpretación del pronombre

A continuación, mostramos que varios elementos del contexto lingüístico del pronombre influyen en la interpretación que tenemos del pronombre uno. Un análisis cualitativo detallado de las ocurrencias encontradas en nuestro corpus, así como otros estudios existentes sobre estrategias impersonales (De Cock (a) ms., Fernández Soriano y Táboas Baylín (1999), Hernanz (1990))), permiten determinar qué elementos tienen un impacto en su interpretación.

En este artículo, nos centramos en los factores que proceden del contexto amplio, a saber más allá de la oración o del verbo conjugado, porque este tipo de factores no ha recibido mucha atención en la investigación sobre el pronombre indefinido uno (y los impersonales en general), al contrario de elementos del nivel de la oración o del verbo (el aspecto verbal, el tiempo verbal, la presencia de verbos modales, el tipo de verbo (si es pronominal o no pronominal) y una oración condicional lógica) (Ridruejo, 1981, Fernández Soriano y Táboas Baylín, 1990: 1732-1737, Bidot Martínez, 2008: 76-82). En efecto, varios factores que se encuentran en un contexto más amplio que la oración impactan en su interpretación.

Distinguimos dos clases de factores, que influyen de manera opuesta en la interpretación del pronombre. Por una parte, diferenciamos los factores que reducen su referencia (4.1.). Por otra parte, identificamos los elementos de contexto amplio que favorecen una lectura genérica del pronombre. (4.2.) Parte de estos factores están ilustrados en este apartado, a fin de ejemplificar los factores. Varios otros están también ejemplificados en el siguiente 5. Propuesta de tipología., donde describimos de forma detallada cada tipo diferenciado. Dentro de los ejemplos, subrayamos los factores que influyen en la interpretación del pronombre y el pronombre uno está puesto en negrita. 


\subsection{Factores que favorecen una reducción de la referencia}

Los factores que reducen la genericidad de la interpretación de uno son mayoritariamente pronombres $\mathrm{u}$ otros indicios deícticos que se encuentran en el contexto lingüístico del pronombre. Estos pronombres e indicios deícticos pueden referir a “yo” (o “nosotros”) (véase (1), 15), a “tú” (o “vosotros”) (véase (2), en este caso, se trata de un deíctico de la primera persona del singular en el discurso del interlocutor 14) o “él” (o “ellos”) en el discurso del emisor o del receptor.

(1)

$1<$ H1> A mí me encanta como huele lo...

$2<\mathrm{H} 2>$ ¿La higuera?

$3<\mathrm{H} 1><$ ininteligible $>$... tiene que tener los higos.

$4<\mathrm{H} 2>$ Mi abuela tenía una y como de subirte luego te pica todo y eso pues...

$5<$ H3> Yo ¡eh! yo también en una higuera me subía cantidad. Las higueras yo

$6 \quad$ creo que son los árboles donde más fácil se sube uno.

$7 \quad<\mathrm{H} 2>$ Claro.

$8<$ H1 $>$ Claro. (Corlec - CCON034A)

(2)

$1<$ H2> En Alemania, hace... diez años; ocho o diez años, hubo... Bueno,

2 bue $<$ palabra cortada $>$... diez años o más, o veinte, ¿no?, aunque bueno, había movimientos

3 como los $<$ extranjero $>$ Mods $<$ /extranjero $>$ y todo eso, ¿no? (Entonces) este grupo era... uno de

4 los emblemáticos de los <extranjero $>$ Mods $<$ /extranjero $>$. Yo cuando era pequeño... era más

$5<$ <extranjero $>$ Mod $<$ /extranjero $>$ que $<$ extranjero $>$ Rocker $</$ extranjero $>$

$6<$ H3 $><$ risas $>$ ¡Qué gracioso! <risas $>$

$7<$ H1 $><$ risas $>$ Hay que se $<$ palabra cortada $>$... Es que había que ser algo. Cuando uno es pequeño 8 hay que ser algo, ¿eh?

$9<$ H2 $>$ Era o $<$ extranjero $>$ Mod $<$ /extranjero $>$ o $<$ extranjero $>$ Rocker $<$ /extranjero $><$ simultáneo $>$ Y

10 yo era <extranjero $>$ Mod $<$ /extranjero $>$

$11<$ H3> Porque tiene que identificarte con alguna corriente. </simultáneo>

$12<$ H1> Mi hermano... Pablo empezó siendo <extranjero>Mod</extranjero> y a<palabra 13 cortada $>$... y ahora es un $<$ extranjero $>$ Rocker $<$ /extranjero $>$.

$14<$ H3> ¿Sí? (Corlec - ACON024A)

Cuando encontramos estos elementos en el contexto más a menos cercano de uno, la referencia de uno está a menudo relacionada con la referencia establecida mediante estas formas deícticas. El contexto permite determinar si la referencia de las formas 
deícticas puede ser transferida a uno. Para saber si uno y la(s) forma(s) deíctica(s) comparten la misma referencia, hay que conocer el contexto entero de la situación. En algunos casos se repite un verbo con el pronombre uno, que ya se había mencionado anteriormente con la forma deíctica (véase (1), 15). En otros casos, el verbo conjugado con uno forma parte de una cadena de acciones relacionadas, de la que también forma parte la forma deíctica (véase (3), 117).

\section{(3)}

$1<$ H6 $>$ A ver qué tal... el novio de Nuria se ha compra $<$ (d) $>$ o un "Escort".

$2<$ H9> Pues a ver qué tal.

$3<$ H7 $>$ ¿Sí? Pues < simultáneo > como le pase...

$4<$ H6 $>$ Y dice que... $<$ /simultáneo $>$ vamos...

$5<$ H3 $>$ Que va bien.

$6<$ H6> Tampoco le ha teni $<$ (d)>o mucho porque a los siete días se le escoñó.

$7 \quad<$ H9 $>$ ¿De golpe?

$8<$ H6> Lo estropeó él.

$9<\mathrm{H} 3>$ No, le dió un golpe.

$10<$ H6> De golpe, vamos.

$11 \quad(\ldots)$

$12<$ H3> Pero no falla, ¿eh?

$13<$ H6> No. Pero por eso lo... < simultáneo> por eso lo ma<palabra cortada>, por eso lo mandó a la

14 "Ford".

$15<$ H3 $>$ Siempre que tienes un coche nuevo tienes un golpe. $</$ simultáneo $>$

$16<$ H6> O sea, lo mandó a la "Ford", a la... donde lo había comprado.

$17<$ H7 $>$ Es que los coches nuevos... está uno $<$ simultáneo $>$ acostumbra $<$ (d) $>$ o al viejo y vas y coges el 18 nuevo y ¡zas!, el golpe.

$19<$ H6> que allí te lo quitan y te lo ponen más o menos como pueden, vamos. </simultáneo> Igual, 20 porque te cambian las... porque no... El coche no se deformó de nada. (Corlec - CCON019A)

Pueden situarse en proximidad directa de uno o alejados en el discurso. Se encuentran principalmente antes del pronombre pero a veces, aparecen detrás.

Además de los deícticos, también encontramos sintagmas nominales correferentes de uno en el contexto lingüístico, que reducen su genericidad. Estos pueden referir a una tercera persona (de la situación comunicativa (veáse (3), 11) o no) o a un grupo de personas. 
Igualmente, sintagmas adverbiales temporales $\mathrm{y} / \mathrm{o}$ espaciales pueden reducir la referencia de uno. Si un elemento de este tipo se encuentra en el contexto lingüístico del pronombre, la referencia del pronombre está reducida a un grupo que entra en lo delimitado por este elemento. En (4, 13), encontramos este tipo de reducción a partir de un adverbio temporal (antes).

(4)

1 (...) Ya le mencioné a los psicólogos. ¿Los ha vito? [sic] Son tan interesantes me refiero a los 2 que dan terapias. Arreglando problemas tan antiguos como la humanidad misma con sus escasos

3 cien años de existencia. Antes uno(1) se deprimía por culpa de los astros y los fados; así pues, uno(2)

4 podía tener la suerte de nacer malencólico. Hoy no, Hoy todos tenemos la misma oportunidad.

5 Bendita democracia. Ya ve, le dije que no era clasista, o al menos no tanto. Espere, regresemos a 6 los psicólogos. (...) [sic] (CLAE)

La reducción de la referencia puede ser más o menos importante, dependiendo, entre otras cosas, de la cantidad de indicios y de su proximidad al uno, así que de la presencia de factores que favorecen una lectura genérica (véase el próximo apartado). La interpretación de uno puede desde luego estar reducida a un grupo más o menos largo y más o menos definido, a una persona (o dos) y generalizarse o reducirse a una persona específica (véase 5. Propuesta de tipología).

\subsection{Factores que favorecen una lectura genérica de uno}

En contraste con los factores que reducen la referencia del pronombre, distinguimos los elementos del contexto que apoyan, al contrario, una lectura genérica de uno, además de los factores ya estudiados anteriormente (véase 2. Estado de la cuestión).

Dentro de ellos, contamos varios mecanismos impersonales en el contexto lingüístico del pronombre: el “tú” genérico (Kluge, 2010), la primera y tercera persona del plural impersonal, el "se" impersonal (véase (5), 117), la tercera persona del singular indefinida y hay/hay que. Cuando están colocados en el contexto del pronombre indefinido uno, estos mecanismos impersonales tienen como efecto de favorecer una lectora genérica del pronombre.

1 Pregunta: 
2 Que [sic] es la muerte y que pasa cuando uno muere?

3 Respuesta:

4 Biológicamente:

5 Es el fin al proceso eléctrico del corazón. El cual deja de bombear, realizar los pulsos, para

6 poder mover la sangre por todo el cuerpo, al dejar de recibir sangre los demás órganos, no

7 tienen como sacar la energía de los alimentos, por lo tanto, todo el sistema humano deja de funcionar.

8 Espiritualmente:

9 Es cuando el alma de todos los seres, deja el cuerpo humano para realizar su ultimo [sic] viaje,

10 a donde, eso solo lo saben los muertos, todas las religiones te crean un camino, pero solo los

11 que se han muerto lo pueden saber, los que han estado a punto de morir, ven una luz brillante al

12 final de un tunel, pero mas alla, nada mas. [sic]

13 OBS: cuando uno muere pierde 15 gramos de peso, que se concluyo [sic], estudio médico, que 14 era el peso del alma. (YCCQA)

De forma más general, otro factor es la presencia de un contexto genérico, indefinido o vago, que comprende varios elementos distintos, entre los cuales encontramos los “inductores de genericidad” (Fernández Soriano y Táboas Baylín (1999), Hernanz (1990)), como los adverbios siempre, a menudo, etc.. Nosotros, además de los “inductores de genericidad”, incluimos en esta categoría cualquier elemento que tiene significación vaga, indefinida, absoluta o imprecisa. Así, añadimos cuantificadores (p.e. mucho), adverbios temporales que inducen imprecisión o genericidad (p.e. a veces), elementos modales (p.e. es posible que), infinitivos, modalizadores imprecisos (p.e. tal), léxico con semántica indefinida o genérica (veáse (2) con todos los seres, el cuerpo humano), etc..

Estos factores, cuando se hallan en el contexto lingüístico de uno, producen de manera general genericidad e influyen en la manera con la que se interpreta uno, contribuyendo a una lectura genérica del pronombre.

\section{Propuesta de tipología}

El estado de la cuestión (2. Estado de la cuestión) muestra que algunos investigadores reconocen que existen varias referencias posibles del pronombre indefinido uno. También se estipula que las interpretaciones distintas dependen del contexto. Entre las categorías propuestas, siempre encontramos un tipo más o menos específico que corresponde al emisor. Generalmente también se propone un tipo más bien general, con referencia a todo el mundo. 
Luego, la aparición en el contexto lingüístico del pronombre uno de factores que influyen en su interpretación (4. Factores que influyen en la interpretación del pronombre) muestra que la referencia no siempre es la misma (p. ej. genérica) y que varía en función del contexto lingüístico. Estos factores además permiten observar tendencias interpretativas. Ayudan a poner en evidencia distintos tipos del pronombre, en cuanto a su referencia.

Presentamos a continuación nuestra propia tipología de uno indefinido, elaborada tras un estudio profundizado y detallado de las ocurrencias encontradas en nuestro corpus y de los factores que influyen en su interpretación, prestando una atención especial a su referenccia. Nos inspiramos, además, de los estudios y des las tipologías de Siewierska (2011), de Gelabert-Desnoyer (2008) y de Coussé y van der Auwera (2012). Un aspecto importante que queremos destacar es que el pronombre se interpreta de varias maneras en función del contexto en el que aparece.

\subsection{Tipología general}

Distinguimos los tipos siguientes de uno (véase Tabla 2), que se sitúan en un continuo entre el polo completamente genérico y el polo completamente específico (véase Tabla 1). El contexto lingüístico y extralingüístico, o más precisamente los factores detallados en 4. Factores que influyen en la interpretación del pronombre, nos permiten determinar a quién refiere el pronombre y contribuyen a la clasificación de las ocurrencias encontradas.

Tabla 1. Tipología de uno simplificada

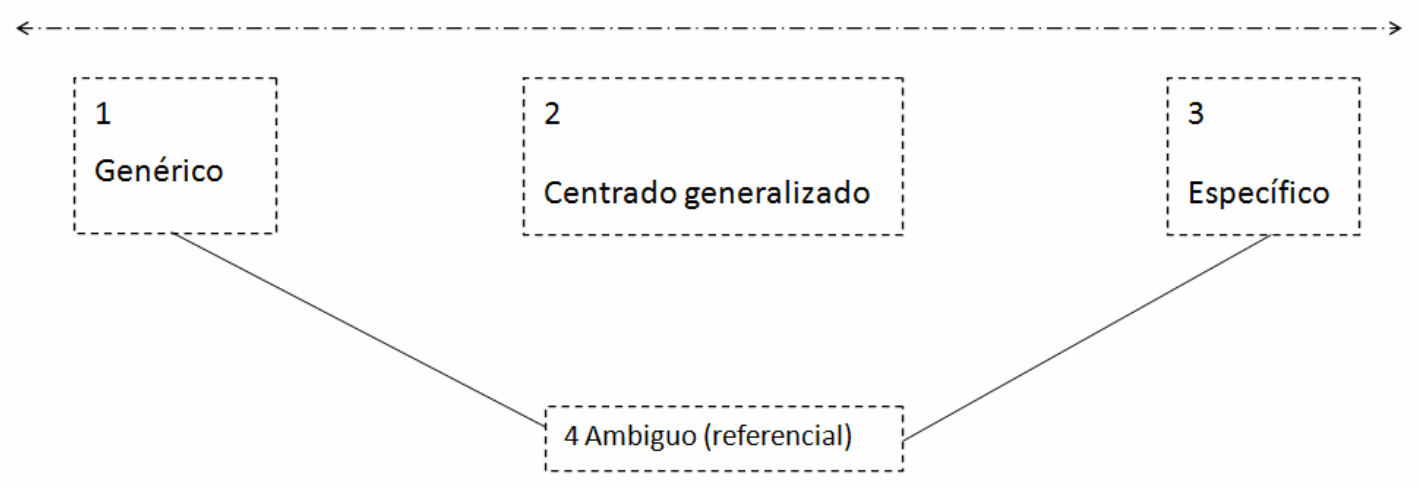

La Tabla 1 muestra una forma simplificada de la tipología desarrollada en nuestro estudio. Esquematiza sus categorías generales: Los tipos “específico” y “genérico” están 
colocados en los extremos de un continuo. Otra categoría general "centrado generalizado” está situada entre los dos extremos. Al lado de estas, una cuarta categoría general "ambiguo" se aleja del continuo. La Tabla 2 detalla la tipología con una subdivisión de cada categoría.

Tabla 2. Tipología de uno

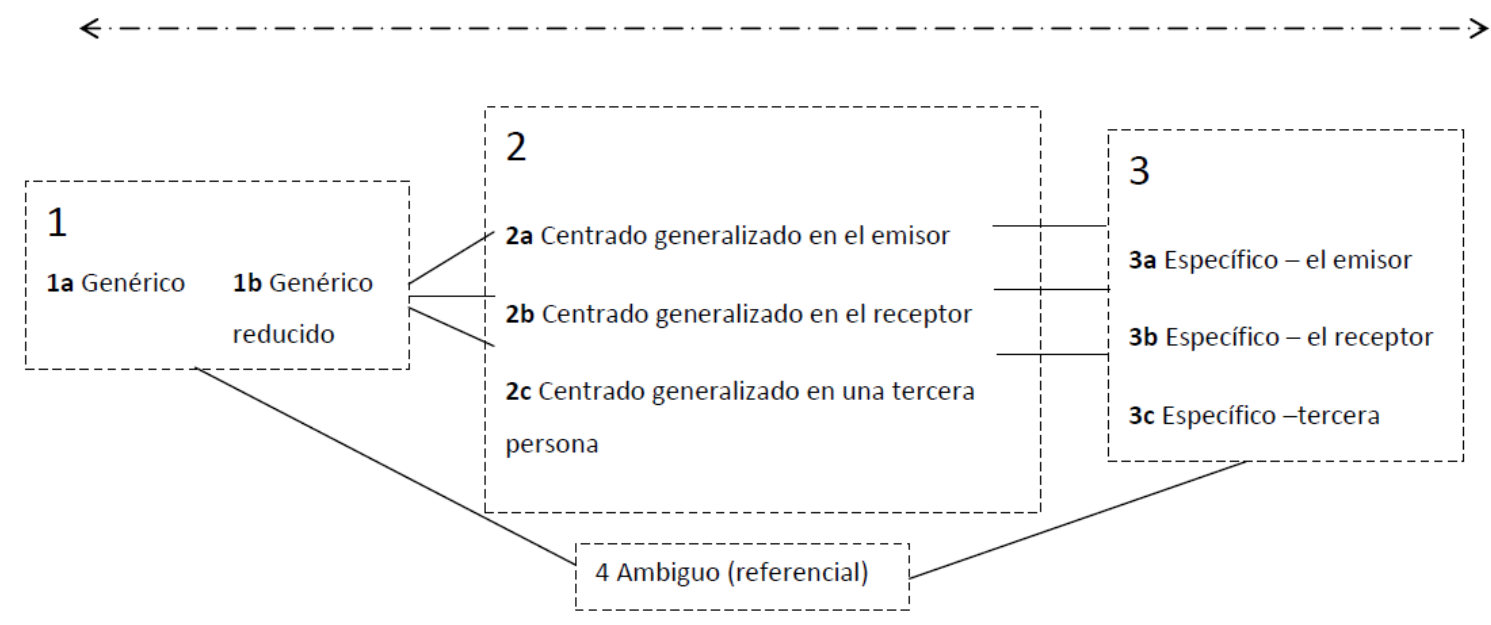

A continuación, describimos y ejemplificamos los varios tipos propuestos en nuestra tipología.

\subsection{1a. Tipo genérico}

En primer lugar, en el tipo "genérico” (1a), la referencia puede ser todo el mundo, es decir que puede incluir al receptor, al emisor y a cualquier otra persona. Corresponde al tipo “omnipersonal” en Gelabert-Desnoyer (2008: 413) y al uso "humano genérico” en Coussé y van de Auwera (2012: 121-122). El ejemplo (5) ilustra este uso.

\footnotetext{
1 Pregunta:

2 Que [sic] es la muerte y que pasa cuando uno muere?

3 Respuesta:

4 Biológicamente:

5 Es el fin al proceso eléctrico del corazón. El cual deja de bombear, realizar los pulsos, para

6 poder mover la sangre por todo el cuerpo, al dejar de recibir sangre los demás órganos, no

7 tienen como sacar la energía de los alimentos, por lo tanto, todo el sistema humano deja de funcionar.
} 
9 Es cuando el alma de todos los seres, deja el cuerpo humano para realizar su ultimo [sic] viaje,

10 a donde, eso solo lo saben los muertos, todas las religiones te crean un camino, pero solo los

11 que se han muerto lo pueden saber, los que han estado a punto de morir, ven una luz brillante al

12 final de un tunel, pero mas alla, nada mas. [sic]

13 OBS: cuando uno muere pierde 15 gramos de peso, que se concluyo [sic], estudio médico, que 14 era el peso del alma. (YCCQA)

Este ejemplo, sacado del corpus YCCQA, contiene dos ocurrencias de uno indefinido del tipo completamente genérico. En el primer caso, el pronombre está colocado en una pregunta muy general sobre un tema general que concierne todos los seres humanos: la muerte. Aquí, claramente, uno refiere a cualquier persona.

Luego, en la respuesta, también se usa un pronombre indefinido uno para hablar del mismo tema general, retomando además las mismas palabras que en la pregunta cuando uno muere (12- 113), lo que favorece aún más la misma lectura genérica.

Observamos que se usan términos muy generales desde el punto de vista semántico, a saber otras referencias genéricas, p.ej. el cuerpo humano (19), el sistema humano (17), todos los seres (19), los muertos (110), así que otros mecanismos impersonales como por ejemplo la $2^{\text {a }}$ persona singular impersonal (110) (Kluge, 2010, 2012) y el "se" impersonal (113). Al contrario, este fragmento no contiene ninguna referencia a ninguno de los interlocutores ni a una persona específica. Desde luego, el contexto también crea una lectura genérica.

Como lo muestra el ejemplo anterior, la ausencia de factores que reducen la referencia del pronombre (veáse 4.1. Factores que favorecen una reducción de la referencia) implica generalmente que uno se interpreta de manera genérica (también si no se encuentran factores que favorecen una lectura genérica del pronombre en su contexto lingüístico).

\subsection{1b. Tipo genérico reducido}

En el tipo genérico reducido (1b), el pronombre se interpreta también como genérico pero, gracias al contexto, se puede excluir parte de la población o delimitar un grupo a quien hace referencia uno. Sin embargo, el grupo no permite determinar referentes 
precisos, porque la referencia sigue siendo general. Es parecido al tipo “impersonales no referenciales” de Coussé y van der Auwera (2012:122), a la diferencia de que en nuestro tipo, el grupo puede haber sido mencionado anteriormente, lo que ambos autores excluyen explícitamente en su categoría de “impersonales no referenciales”. Encontramos también similitud con los tipos “corporativo” y "universal” de la tipología de Siewierska y Papastathi sobre la tercera persona plural impersonal (2011: 581-582). Para los universales, la identificación del referente se hace gracias a una expresión locativa, para los corporativos, se hace a partir del verbo y del argumento verbal.

En el tipo genérico reducido de nuestra tipología, la referencia típicamente se reduce por una restricción temporal o espacial. A continuación, damos un ejemplo (4) del tipo genérico reducido por una restricción temporal. Se trata de un extracto de ensayo sobre la depresión, escrito por un estudiante.

1 (...) Ya le mencioné a los psicólogos. ¿Los ha vito? [sic] Son tan interesantes me refiero a los

2 que dan terapias. Arreglando problemas tan antiguos como la humanidad misma con sus escasos

3 cien años de existencia. Antes uno(1) se deprimía por culpa de los astros y los fados; así pues, uno(2)

4 podía tener la suerte de nacer malencólico. Hoy no, Hoy todos tenemos la misma oportunidad.

5 Bendita democracia. Ya ve, le dije que no era clasista, o al menos no tanto. Espere, regresemos a

6 los psicólogos. (...) [sic] (CLAE)

\subsection{2a. Tipo centrado generalizado en el emisor}

En varios casos, uno no se interpreta de forma completamente generalizada, pero tampoco hace referencia a una persona específica. En el tipo “centrado generalizado en el emisor” (2a), la interpretación del pronombre se construye de la manera siguiente: partimos de la persona que habla o escribe, que a menudo refiere a una experiencia personal y la generaliza a un grupo más largo. A veces, el mecanismo opera en sentido inverso, a saber que se generaliza y, después, la referencia se centra en el emisor.

Este uso es por un lado semejante a los tipos "uno exclusivo" y "uno inclusivo" de Rodríguez Alfano (2004: 198-199), presentados como representante prototípico de un grupo de gente, excluyendo (en el primer caso) o incluyendo (en el segundo) el 
interlocutor. Por otro lado, es parecido al tipo "auto-referencial experiencial” de Gelabert-Desnoyer, definido como relacionado íntimamente con el hablante, aunque con un grado menor que el auto-referencial, lo que permite una apertura de referencia hacia otros (2008). Kluge (2012: 91), en su tipología construida a partir de cinco puntos focales sobre la segunda persona del singular genérica, describe un tipo similar: la referencia al hablante como representante típico de una entidad más larga.

En el ejemplo (1), mencionado ya anteriormente y repetido aquí, este proceso está ilustrado en una conversación entre tres estudiantes

$1<$ H1 > A mí me encanta como huele lo...

$2<\mathrm{H} 2>$ ¿La higuera?

$3<\mathrm{H} 1><$ ininteligible $>$... tiene que tener los higos.

$4<$ H2 $>$ Mi abuela tenía una y como de subirte luego te pica todo y eso pues...

$5<$ H3> Yo ¡eh! yo también en una higuera me subía cantidad. Las higueras yo $6 \quad$ creo que son los árboles donde más fácil se sube uno.

$7 \quad<$ H2 $>$ Claro.

$8<$ H1 $>$ Claro. (Corlec - CCON034A)

Constatamos que el hablante que usa el pronombre uno (H3), describe su propia experiencia en la frase anterior haciendo claramente referencia a sí mismo (uso de yo o de indicios de primera persona del singular (me) varias veces (15)). Además, el lazo con el pronombre uno está reforzado por la repetición del verbo conjugado en la primera persona del singular y en tercera con uno como sujeto: subir (15 - 16). Sin embargo, la frase con el pronombre indefinido generaliza a un grupo más largo que sólo el hablante. Lo deducimos a partir del contexto amplio, incluyendo la situación de comunicación (el hecho de que los tres estudiantes hablan de higueras y que cada uno comparte su experiencia, y el carácter informal e interaccional). Además, encontramos en el contexto varios elementos con semántica general o indefinida (las higueras (15)), así que otros mecanismos impersonales (se impersonal (16)), que fortalecen esta lectura. 


\subsection{2b. Tipo centrado generalizado en el receptor}

El tipo centrado generalizado se presenta igualmente con una interpretación partiendo del receptor (2b). La literatura no menciona este tipo de uso de uno, excepto De Cock (2014 (b): 111-112), que muestra que uno puede referir en primer lugar al interlocutor, lo que se deduce a partir del contexto lingüístico amplio. Permite al hablante mostrar solidaridad con el interlocutor y tiene desde luego una función intersubjetiva. Sin embargo, no se describe en detalle el mecanismo interpretativo y, aunque menciona el tipo “otro-referencial”, de Gelabert-Desnoyer (2008), que exclusivamente refiere al interlocutor, no se especifica en qué se diferencia de este tipo “otro-referencial”.

En el ejemplo siguiente, repetido una segunda vez, se puede observar este funcionamiento.

$1<$ H2> En Alemania, hace... diez años; ocho o diez años, hubo... Bueno,

2 bue $<$ palabra cortada $>$... diez años o más, o veinte, ¿¿no?, aunque bueno, había movimientos

3 como los $<$ extranjero $>$ Mods $<$ /extranjero $>$ y todo eso, ¿no? (Entonces) este grupo era... uno de

4 los emblemáticos de los $<$ extranjero $>$ Mods $</$ extranjero $>$. Yo cuando era pequeño... era más

$5<$ <extranjero $>$ Mod $<$ /extranjero $>$ que $<$ extranjero $>$ Rocker $<$ /extranjero $>$

$6<\mathrm{H} 3><$ risas $>$ iQué gracioso! $<$ risas $>$

$7<$ H1 $><$ risas $>$ Hay que se $<$ palabra cortada $>$... Es que había que ser algo. Cuando uno es pequeño

8 hay que ser algo, ¿ंeh?

$9<$ H2 $>$ Era $0<$ extranjero $>$ Mod $<$ extranjero $>0<$ extranjero $>$ Rocker $<$ /extranjero $><$ simultáneo $>$ Y

10 yo era $<$ extranjero $>$ Mod $<$ /extranjero $>$

$11<$ H3> Porque tiene que identificarte con alguna corriente. $</$ simultáneo $>$

$12<$ H1 > Mi hermano... Pablo empezó siendo <extranjero $>$ Mod</extranjero $>$ y a $<$ palabra 13 cortada $>$... y ahora es un $<$ extranjero $>$ Rocker $<$ /extranjero $>$.

$14<\mathrm{H} 3>$ ¿Sí? (Corlec - ACON024A)

En (2), uno se conjuga también con el mismo verbo (y atributo) que se empleó en un turno de palabra anterior, con el pronombre personal de primera persona del singular pero formulado por el interlocutor (o receptor) (H2): ser pequeño (14 - 17). Por lo tanto, encontramos aquí referencias directas a este interlocutor (H2) (yo, era en su propio discurso (14)). El pronombre uno usado por H1 poco después retoma desde luego la referencia del yo-interlocutor y lo generaliza a un grupo más largo, en este caso, indefinido. La generalización está reforzada por varios elementos generales, 
indefinidos, impersonales o vagos que encontramos en el contexto lingüístico, como son la semántica de las palabras (algo (17 - 18)), otros mecanismos impersonales (había que, hay que (17 - 18)) o marcadores discursivos atenuantes (es que (17)) (Rasson, 2012: 60). Los atenuantes, en varios casos, transmiten incertidumbre o tienen la función de borrar el emisor para evitar perjudicar la imagen del emisor o del receptor (face threatening acts (FTAs), Brown y Levinson, 1987). Estos atenuantes, por su función, transmiten desde luego un carácter impreciso/ borrado.

En este ejemplo, se puede explicar el uso de uno generalizando a partir del interlocutor con una función pragmática de atenuar el daño que se hace a la imagen de este interlocutor. Divulgó en efecto una información sobre sí mismo, que se podría ver como vergonzosa. Además, otro participante en la situación de comunicación (H3) abiertamente se ríe de H2 (16) y daña su imagen. El proceso de usar uno para generalizar lo que dijo el interlocutor H2 es entonces una manera de “reparar” la imagen dañada.

En este ejemplo, constatamos que el pronombre uno refiere también a los seres humanos en general, como en el tipo genérico (1a), que incluye en su referencia todo el mundo pero la restringe a un periodo temporal (vago, en este caso), claramente detectable gracias al adverbio temporal antes (13) y al uso del tiempo pasado. Desde luego, deducimos que este uso es menos genérico que el primer uso, completamente genérico. Observamos que, aunque encontramos varias referencias a participantes específicos (la persona que escribe con referencia a sí mismo (mencioné, me refiero (l1)), la referencia al lector (le, ha visto (11)), también encontramos una serie de elementos que contribuyen a una lectura genérica: la humanidad (12), todos (14).

\subsection{2c. Tipo centrado generalizado en una tercera persona}

El tipo centrado generalizado existe también partiendo de una tercera persona (2c). El funcionamiento anterior se aplica del mismo modo con una referencia en el contexto lingüístico a una tercera persona, que no es el hablante pero tampoco el interlocutor. Este tipo de uno, según nuestras informaciones, no ha sido analizado en la literatura. En (3), un ejemplo repetido una secunda vez, los interlocutores hablan de un acontecimiento que implica el novio de Nuria. 
(3)

$1<$ H6> A ver qué tal... el novio de Nuria se ha compra $<$ (d) $>$ o un "Escort".

$2<$ H9 $>$ Pues a ver qué tal.

$3<\mathrm{H} 7>$ ¿Sí? Pues <simultáneo $>$ como le pase...

$4<$ H6> Y dice que... </simultáneo $>$ vamos...

$5<$ H3> Que va bien.

$6<$ H6> Tampoco le ha teni $<$ (d) $>$ o mucho porque a los siete días se le escoñó.

$7 \quad<\mathrm{H} 9>$ ¿De golpe?

$8<$ H6> Lo estropeó él.

$9<\mathrm{H} 3>$ No, le dió un golpe.

$10<$ H6> De golpe, vamos.

$11 \quad(\ldots)$

$12<\mathrm{H} 3>$ Pero no falla, ¿eh?

$13<$ H6> No. Pero por eso lo... < simultáneo $>$ por eso lo ma<palabra cortada $>$, por eso lo mandó a la

14 "Ford".

$15<$ H3> Siempre que tienes un coche nuevo tienes un golpe. $</$ simultáneo $>$

$16<$ H6> O sea, lo mandó a la "Ford", a la... donde lo había comprado.

$17<\mathrm{H} 7>$ Es que los coches nuevos... está uno $<$ simultáneo $>$ acostumbra $<$ (d) $>0$ al viejo y vas y coges el

18 nuevo y izas!, el golpe.

$19<$ <6> que allí te lo quitan y tee lo ponen más o menos como pueden, vamos. </simultáneo> Igual,

20 porque te cambian las... porque no... El coche no se deformó de nada. (Corlec - CCON019A)

Los hablantes cuentan y comentan un accidente sufrido por el novio de Nuria (11). H7 usa el pronombre uno indefinido, haciendo referencia en primer lugar a este último y luego generalizando a un grupo largo indefinido que podría ser todo el mundo. Se hace varias veces referencia a esta tercera persona (el novio de Nuria, le (16), él (18), dio (19), mandó (116), había (116)), lo que establece el punto de partida de la lectura interpretativa. Además, varios indicios de genericidad y indefinitud del contexto lingüístico amplio refuerzan el carácter generalizador. Encontramos en este ejemplo, por un lado, palabras con semántica general: siempre (115). Por otro lado, hallamos varios mecanismos impersonales, como el “tú” genérico (tienes (115), te (119), vas (117), coges (117), etc.) y la tercera persona del plural indefinida (quitan (119), cambian (120)).

El uso de uno en este ejemplo, como en el anterior, se relaciona igualmente con cierta forma de empatía con la persona a la que se refiere (en este caso, el novio de Nuria). El tema del que se habla es delicado y le puede perjudicar. El empleo del indefinido uno 
asocia el hablante y la gente en general con su desgracia. Así, la imagen dañada de la tercera persona es, de cierta forma, reparada.

\subsection{3a. Tipo específico - el emisor}

El tipo específico que corresponde al emisor (3a) ha sido descrito por varios autores (véase apartado 2. Estado de la cuestión). Aquí, a diferencia del tipo “centrado generalizado en el emisor”, no hay una voluntad evidente de generalizar la referencia a un grupo más largo de personas. Al contrario, es otra forma de referirse al “yo”.

¿Que cómo sé tanto al respecto? Uno se entera de esas cosas. Es tan divertido; por supuesto me

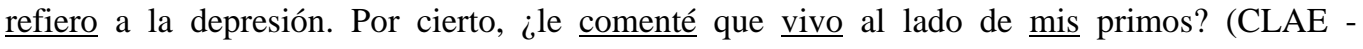
MLtEn20)

Observamos en (6) que las referencias al emisor son numerosas (sé, me refiero, comenté, vivo, mis) y que rodean la ocurrencia de uno. En cambio, sólo encontramos una palabra con sentido vago (esas cosas). Otro elemento que tiene un impacto en la interpretación de uno es el hecho que el autor contesta a su propia pregunta sobre sí mismo y que desde luego, suponemos que habla de sí mismo. El uso de uno en (6) sirve pues para evitar ponerse en evidencia, proteger su propia imagen pero también para dar más peso evidencial a lo que dice (Scheibman, 2007: 129-134).

\subsection{3b. Tipo específico - el receptor y tipo específico - una tercera persona}

Estos dos tipos no han sido encontrados en nuestros corpus. Sin embargo, el tipo específico (receptor) (3b), ha sido encontrado frecuentemente en discursos parlamentarios por Gelabert-Desnoyer (2008), que lo llama “otro-referencial”.

1 El señor VICEPRESIDENTE SEGUNDO DEL GOBIERNO PARA ASUNTOS ECONÓMICOS Y

2 MINISTRO DE ECONOMÍA (De Rato y Figaredo): Tengo que decir dos cuestiones más, si me da

3 tiempo. La primera, señor Caldera, es que cuando se confeccionan dossieres sobre familiares de

4 adversarios políticos con datos protegidos por la ley, uno debe ser consciente de las consecuencias de

5 sus actos. En segundo lugar, señor Caldera, y sobre la actividad económica, les voy a dar un consejo

6 al señor Rodríguez Zapatero, aquí presente, y a usted: no espere una desaceleración económica. 
En (7), uno es usado para rechazar el punto de vista del oponente. En este caso, encontramos dos co-referencias al interlocutor (señor Caldera 13- 15)), en el contexto lingüístico cercano al uno y que lo rodea. Se entiende fácilmente que refiere a este señor a partir del contexto. Permite atacar el oponente sin violar las reglas del parlamento español (Gelabert-Desnoyer, 2008: 419-421). El pronombre uno desempeña aquí una función de evitar dañar la imagen de interlocutor (face threatening acts (FTAs), Brown y Levinson, 1987).

\subsubsection{Tipo ambiguo (referencial)}

En el tipo ambiguo de uno indefinido, la interpretación depende más del contexto situacional que en los otros tipos. En otras palabras, este tipo se interpreta a partir de los participantes de la situación comunicativa. El pronombre no hace referencia a todo el mundo o a una persona precisa, sino que hace referencia a cualquiera o algunas de las personas de la situación de comunicación. El receptor sabe a qué personas posibles se refiere, sin por lo tanto poder identificar precisamente de quién se trata en particular (ni el receptor ni una persona externa a la discusión puede identificar con certeza de quién se trata precisamente). La referencia queda por lo tanto ambigua. El pronombre hace referencia a una persona en un pequeño grupo de personas que conocemos, dado que forman parte de la situación comunicativa. Este tipo de uno no ha sido mencionado en la literatura, salvo por Coussé y van der Auwera (2012) que mencionan un tipo similar. Coussé y van der Auwera hablan de un tipo de “man-impersonals” (man-imp) que sirve para guardar vaga la identidad del referente, el llamado tipo "indefinido referencial" (2012). Sin embargo, su análisis no toma en cuenta los participantes en la situación comunicativa.

El ejemplo (8) muestra un caso de uno de tipo vago donde el referente puede ser H3 o Teresa. Se trata de una discusión telefónica entre dos amigas (H1 y H3) sobre una tarjeta que permite entrar en la piscina de H1.

$1<$ H1> Que... ¿¿ú quieres venir a mi piscina?

$2<$ H3> Claro. Sí. 
$3<\mathrm{H} 1>$ Eh... pero tienes que venir todos los días, porque verás. Resulta que aquí, que son muy así...

$4<$ H3> Sí.

$5<\mathrm{H} 1>$... les dijimos... les preguntamos si podíamos traer invitados,

$6<\mathrm{H} 3>$ Sí.

$7<\mathrm{H} 1>$, y nos dijeron que no, porque la gente se colaba y... tararí y tarará. Total, que nos han

8 dado a cada uno un pase, que pone nuestro nombre, y además, en la piscina arriba te piden el

9 carné de identidad. Pero resulta que cada apartamento tiene derecho a 3 pases.

$10<\mathrm{H} 3><$ fático=afirmación $>$

$11<$ H1 $>$ Entonces, Simón tie $<$ palabra cortada $>$... tiene el suyo, yo tengo el mío y... tenemos que...

12 decidir... el nombre del tercer pase. Entonces, si tú vas a venir todos los días, pues lo pongo a $\underline{\text { tu}}$

13 nombre. Pero tienes que venir mucho, para amortizarlo, ¿eh? Si no, lo pongo a otro nombre.

$14<$ H3> Pero... pero q<palabra cortada > ... que... pero sí, claro; pero ¿̨ahora en época de exámenes?

$15<$ H1> Empieza en junio. <ininteligible > Se abre en junio... y termina luego.

$16<$ H3 $>$ Ah, vale.

$17<\mathrm{H} 1>$ Es que... termina en agosto o así. Es que ahora va a venir Tere. Teresa va a venir en junio.

$18<$ H3 $>$ Sí.

$19<\mathrm{H} 1>\mathrm{Y}$ va a estar aquí, en casa.

$20<\mathrm{H} 3>\dot{\mathrm{C}}<$ ininteligible $>$ un pase un mes y otro pase otro mes?

$21<\mathrm{H} 1><$ fático=duda $>$ lo vamos a preguntar, si se puede. Si se puede, pues en junio pondremos a

22 Teresa...

$23<$ H3> Claro.

$24<$ H1 $>$ En te<palabra cortada $>$.. y luego ya te ponemos a tí.

$25<$ H3 > Y si no, pues cuando se vaya Teresa yo uso su pase.

$26<$ H1 > Bueno, tú... No, porque tienes que tener su carné de identidad. Si pone el nombre, y todo...

$27<$ H3> (Decís): "Esa persona ya no vive ahí, que ahora vive otra", ¿no?

$28<\mathrm{H} 1>$ No sé, no sé. No sé, no sé. Pero bueno, que... si vienes y si te apetece, pues...

$29<$ H3> ¿Qué?

$30<$ H1 $>$ Que si vienes y te apetece, ya sabes. Se abre el día 1 de junio.

$31<$ H3> Gracias, pero yo empiezo con los exámenes.

$32<\mathrm{H} 1>$ Ya.

$33<$ H3> Oye, pero... y no se puede uno colar, ¿no?

$34<$ H1 $>$ No. (Corlec - ACON023A)

En este ejemplo, se entiende que uno puede hacer referencia a H3 (que quiere ir a la piscina pero que tiene exámenes) o a Teresa (que va a venir en junio), probablemente una amiga o una familiar de H1. Esta deducción se hace gracias al contexto lingüístico amplio. Se necesita conocer la situación para encontrar los referentes. En cuanto a 
indicios lingüísticos precisos, encontramos varias referencias a estos dos participantes mediante formas deícticas de primera y segunda persona del singular. Además, el verbo conjugado con uno (colarse) ha sido conjugado anteriormente con la gente (17), lo que favorece una lectura vaga (o genérica). Asimismo, hallamos varios mecanismos impersonales o indefinidos: el tú genérico (18), la primera y tercera persona del plural indefinida, el "se” impersonal (te piden, dijeron, podíamos, se puede, etc. (15-7-8-2130)) con este mismo efecto.

Nuestra tipología propone varios tipos de uno indefinidos a partir de la interpretación que se hace del pronombre. La elaboramos a partir de un estudio profundizado de las ocurrencias encontradas en los corpus estudiados. En algunos casos, retomamos o nos inspiramos de tipologías existentes. Por otro lado, algunos tipos no han sido descritos en los estudios de este pronombre, según nuestro conocimiento. Se trata del pronombre uno “centrado generalizado” en el receptor y en una tercera persona.

En algunos casos, las ocurrencias no se pueden clasificar en la tipología desarrollada. Por eso, añadimos el apartado siguiente que trata con estos casos particulares.

\subsection{Posiciones intermediarias en el continuo}

Como lo mencionamos en el principio del apartado 5. Propuesta de tipología, la tipología que desarrollamos intenta mostrar los distintos matices interpretativos y las distintas lecturas que existen del pronombre indefinido uno. Además, se trata de tipos que situamos en un espectro entre los polos completamente genérico y completamente específico. Desde luego, los casos encontrados no se delimitan siempre claramente entre las categorías, aunque la mayoría se clasifica fácilmente en la tipología general (22\% de las ocurrencias se sitúan entre los tipos delimitados). Estos casos intermedios corresponden al funcionamiento del pronombre indefinido que puede inscribirse en el deseo de comunicar de forma vaga.

A continuación, mostramos los casos intermediarios que encontramos en nuestros datos. Algunos de ellos están detallados en este apartado. 
Tabla 3. Tipología de uno con casos intermedios

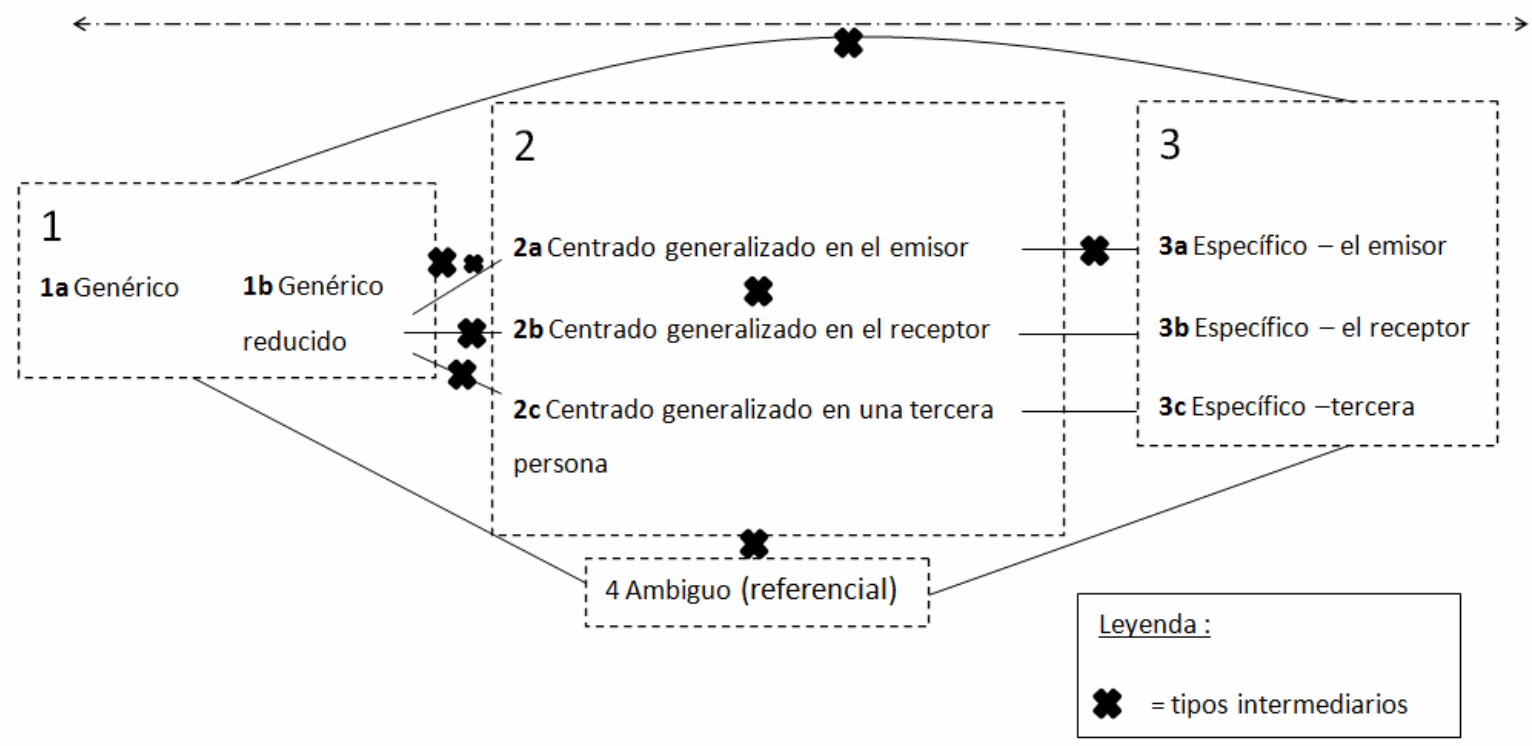

Como lo muestra la tabla 3, de manera general, las ocurrencias que colocamos entre dos tipos generales se sitúan entre un polo del continuum, a saber completamente genérico o completamente específico, y un tipo intermediario, de tipo centrado generalizado. Sin embargo, dentro del corpus YCCQA, encontramos numerosos casos que se sitúan entre 2a y 2b, a saber los tipos “centrados generalizados” en el emisor y en el receptor. Cabe señalar que no encontramos tales casos intermedios en los corpus conversaciones y textos académicos.

A continuación ejemplificamos algunos casos concretos.

5.2.1. Tipo intermediario "centrado generalizado en el emisor y el receptor” (2ab)

En la mayoría de las ocurrencias del corpus YCCQA, interpretamos el uso de uno indefinido como centrado generalizado. Sin embargo, establecer con precisión si la referencia se centra en el emisor o el receptor resulta problemático en varios casos. En efecto, el emisor se basa a menudo en su propia experiencia cuando utiliza uno indefinido. Sin embargo, como se trata frecuentemente de consejos dirigidos a quien formula la pregunta, el emisor intenta extender su experiencia al receptor (lector). Este fenómeno está ilustrado en (9). 
(9)

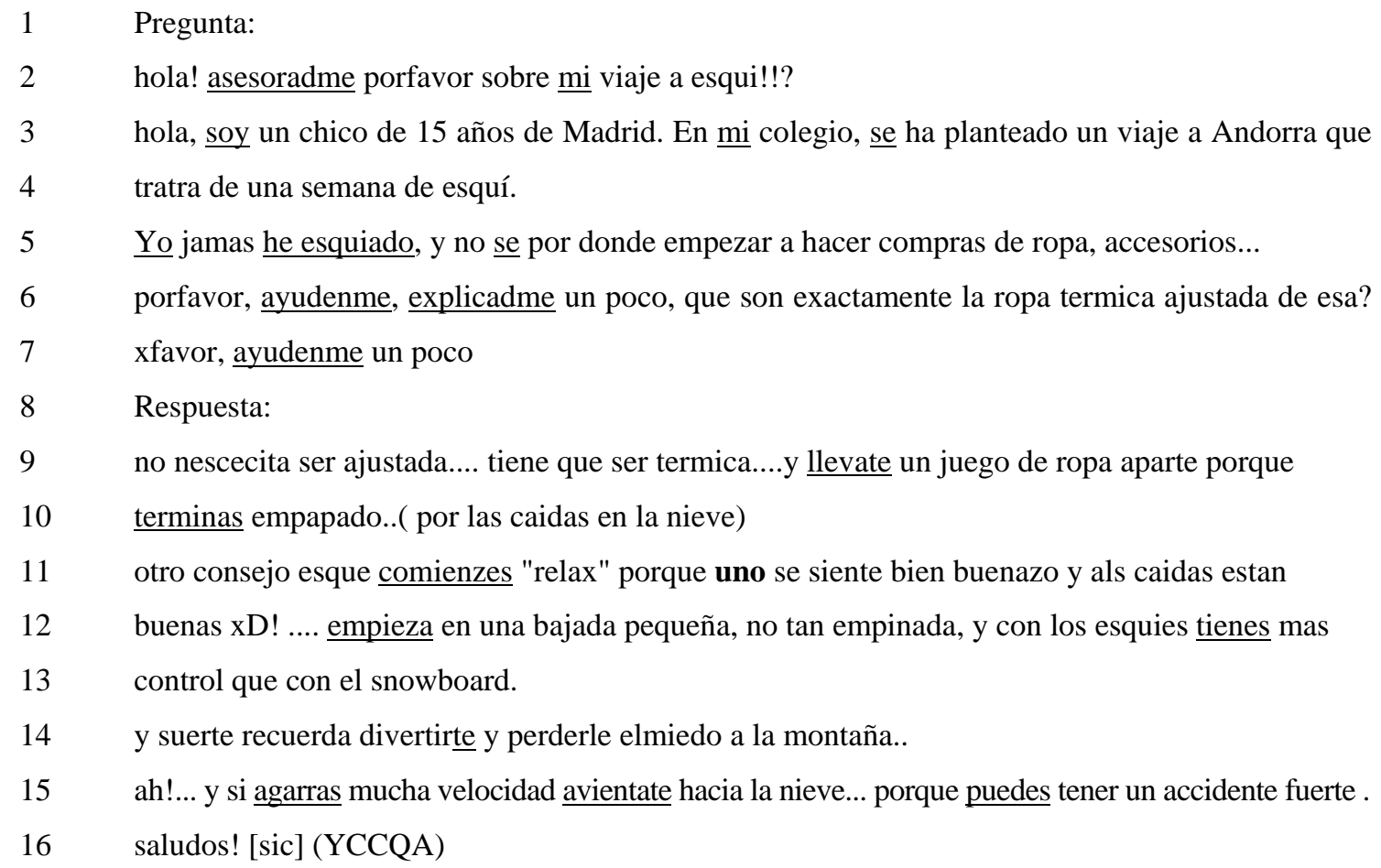

En este ejemplo, notamos que uno se encuentra en una frase donde se habla de una experiencia personal (otro consejo es que comienzes “relax" (112)), para apoyar un consejo de la frase anterior. La experiencia personal se comprende gracias a la situación comunicativa facilitada por la especificidad del género discursivo (foro de preguntas y respuestas) y al contexto lingüístico amplio. Por otro lado, el receptor directo (el preguntador) es también presente en la referencia de uno. Encontramos numerosas referencias explícitas al receptor (comienzes (112), llévate (110), empieza (113), etc.) y constatamos que se quiere aplicar la experiencia del emisor al receptor. El pronombre uno sirve desde luego a relacionar estrechamente el emisor con el receptor.

El uso de este tipo de uno parece favorecido por el género discursivo en cuestión. La estructura pregunta-respuesta, así que el concepto de foro informal que implica el intercambio de opiniones y de experiencias personales apoya este uso específico del pronombre. Permite incluir a la vez la referencia al emisor y al receptor. En efecto, el acto de aconsejar que es típico de este género discursivo puede comprometer las imágenes (faces) de los participantes, lo que favorece el empleo de un pronombre indefinido. La referencia más vaga, que puede abarcar a la vez el emisor y el receptor, reduce el ataque a la imagen. 
5.2.2. Lectura intermediaria entre genérica y centrada generalizada en el receptor (1a 2b)

En una serie de casos, la interpretación de uno se sitúa entre el tipo completamente genérico y un tipo centrado generalizado en un interlocutor. A continuación (ejemplo (10)), ilustramos y explicamos una ocurrencia que se sitúa entre lo completamente genérico y el tipo centrado generalizado en el receptor.

$1<$ H5> Oye, pues mamá no me gusta mucho, estoy llena.

$2<\mathrm{H} 3><$ fático=exclamación $>$

$3<\mathrm{H} 5>$ iQué suerte! La he da $<$ (d) $>$ o una alegría. Como pocas.

$4<\mathrm{H} 2>$ Mamá, mírame a los ojos. Eres una mentirosa. No te puedes

5 engañar. La de Filosofía ha dicho que uno no se puede engañar a sí

6 mismo y no vale decir: "Voy a adelgazar para ponerme la falda" y

7 luego darle...

$8<$ H3 $>$ Hoy puedo comer algo de más que he esta $<$ (d) $>$ o danzando mucho.

$9<$ H2> Sí, hombre. (Corlec - CCON018D)

En (10), uno refiere a la madre, es decir al receptor del mensaje y lo generaliza. Se deduce que la madre es el punto de partida gracias a los deícticos presentes en el contexto lingüístico amplio (Mamá, eres (14)) y la situación comunicativa, a saber la presencia misma de la madre. Encontramos por otra parte indicios de genericidad, como el “tú” genérico te puedes (14). Además, este aspecto genérico está reforzado por la repetición del verbo conjugado (engañar) con uno (15).

La ambigüedad entre el tipo completamente genérico y centrado generalizado en el receptor es la consecuencia de una doble lectura que encontramos en este caso. Por un lado, encontramos la lectura de la de Filosofía que dijo que “uno no se puede engañar”. Esta lectura es completamente genérica dado que no tenía ninguna persona en mente (probablemente) y que lo aplica a todo el mundo. Por otro lado, $\mathrm{H} 2$ aplica lo que dijo la de Filosofía a su madre. Desvela desde luego una doble lectura del pronombre uno indefinido. Estas dobles lecturas, así que la posibilidad de combinar varias lecturas de uno, es una especificidad de este pronombre en comparación con las formas deícticas o anafóricas. 
En esta sección, mostramos que el pronombre indefinido uno puede tener varias interpretaciones distintas en distintos contextos y que estas lecturas son la consecuencia de un serie de factores que se encuentran en el contexto del pronombre. A partir de un análisis detallado de un corpus heterogéneo en cuanto a los géneros discursivos, elaboramos una tipología de las interpretaciones del pronombre indefinido. Los distintos tipos destacados corresponden a tendencias interpretativas que se colocan en un continuo entre dos polos: el polo completamente genérico y el polo específico. En algunos casos, las ocurrencias encontradas en el corpus se colocan entre dos tipos, debido a veces a una doble lectura del pronombre.

\section{Estudio cuantitativo}

\subsection{Frecuencia del pronombre uno en tres géneros discursivos}

En este apartado, comparamos la presencia/ ausencia de uno indefinido en los tres géneros discursivos que presentan las características por una parte menor subjetividad/intersubjetividad y ausencia de interactividad, a saber redacciones académicas de estudiantes (Redac. acad.), y por otra parte, mayor subjetividad/intersubjetividad y interactividad, a saber los dos géneros conversaciones informales espontáneas (Conv.) y preguntas y respuestas en un foro Yahoo (Foro). El análisis cuantitativo del uso de uno en estos géneros nos ofrece una primera aproximación en cuanto a la segunda hipótesis, a saber si el uso de uno indefinido se debe a las características interaccionales del género discursivo y a la mayor presencia de subjetividad/intersubjetividad en el género. A continuación, presentamos la frecuencia de uno indefinido en los tres géneros estudiados.

Tabla 3. Frecuencia de uno indefinido por género discursivo

\begin{tabular}{|l|l|l|l|}
\hline Género discursivo & $\begin{array}{l}\text { Conversación } \\
\text { espontánea }\end{array}$ & $\begin{array}{l}\text { Redacción } \\
\text { académica }\end{array}$ & Foro \\
\hline Número de palabras totales & 240759 & 243900 & 667849 \\
\hline Número de uno en total & 28 & 11 & 100 \\
\hline $\begin{array}{l}\text { Frecuencia de uno/100000 } \\
\text { palabras }\end{array}$ & 11,63 & 4,51 & 14,97 \\
\hline
\end{tabular}


La diferencia de frecuencia de uno entre los géneros estudiados destaca notablemente. Su uso es marcadamente menor en nuestra muestra de redacciones académicas, con 11 casos, que en las conversaciones (28 casos) y en el foro (36 casos en comparación con los demás géneros).

Una prueba binomial en cuanto a estas frecuencias, aplicada a las conversaciones y las redacciones, da un resultado significativo $(\mathrm{p}=0,01$, con un umbral de significatividad de $0,05)$ y nos permite deducir que la diferencia observada, entre las redacciones y las conversaciones (y desde luego también el foro, dado que cuenta aún más ocurrencias que las conversaciones), no se debe al azar. En cambio, la diferencia de frecuencia entre las conversaciones y el foro es demasiado pequeña para concluir a una diferencia de frecuencia significativa.

Concluimos, por lo tanto, de manera provisional, que el pronombre uno se usa menos en redacciones académicas mexicanas que en conversaciones informales espontáneas de España y que en el foro de preguntas y respuestas Yahoo. La segunda hipótesis parece, a partir de estos datos, ser verificada.

\subsection{Estudio cuantitativo de la tipología en los géneros estudiados}

Comparando los tipos de uno encontrados en los tres géneros discursivos estudiados (el foro YCCQA, las conversaciones y las redacciones académicas), observamos diferencias en los usos de uno (tipos diferentes). De manera general, el foro y las conversaciones comparten aproximadamente los mismos tipos (y frecuencias de estos tipos), frente a las redacciones académicas.

Tabla 4. Tipos de uno en cada género discursivo /100000 palabras

\begin{tabular}{|l|l|l|l|}
\hline & $\begin{array}{l}\text { Conversación } \\
\text { espontánea }\end{array}$ & $\begin{array}{l}\text { Redacción } \\
\text { académica }\end{array}$ & Foro \\
\hline Genérico (1a) & 1,66 & 0,41 & 3,74 \\
\hline Genérico reducido (1b) & 0,83 & 2,05 & 0,15 \\
\hline Centrado generalizado en el emisor (2a) & 0,83 & 1,23 & 3,29 \\
\hline Centrado generalizado en el receptor (2b) & 1,25 & 0,00 & 2,70 \\
\hline Centrado generalizado en una tercera & 2,49 & 0,00 & 0,45 \\
\hline
\end{tabular}




\begin{tabular}{|l|l|l|l|}
\hline persona (2c) & & & \\
\hline Específico - emisor (3a) & 0,42 & 0,41 & 0,00 \\
\hline Específico - receptor (3b) & 0,00 & 0,00 & 0,00 \\
\hline Vago (4) & 0,83 & 0,00 & 0,00 \\
\hline Intermediario (1a2a) & 0,42 & 0,00 & 0,90 \\
\hline Intermediario (1a2b) & 0,42 & 0,00 & 0,00 \\
\hline Intermediario (1a2c) & 0,00 & 0,00 & 0,15 \\
\hline Intermediario (1a2ab) & 0,42 & 0,00 & 0,30 \\
\hline Intermediario (1a3ab) & 0,00 & 0,00 & 0,15 \\
\hline Intermediario (2ab) & 0,00 & 0,00 & 2,99 \\
\hline Intermediario (2a3a) & 1,66 & 0,41 & 0,15 \\
\hline Intermediario (2b4) & 0,42 & 0,00 & 0,00 \\
\hline Intermediarios total & 3,32 & 0,41 & 4,64 \\
\hline
\end{tabular}

El uso completamente genérico de uno se encuentra sobre todo en el foro y en las conversaciones (menos en las redacciones, con sólo un caso). En cambio, el tipo "genérico reducido” es más presente en las redacciones (2,05 ocurrencias en frecuencia relativa) que en los dos otros géneros. Luego, el tipo centrado generalizado en el emisor se encuentra en todos los géneros pero con mayor presencia en el foro $(3,29$ proporcionalmente, frente a 0,83 y 1,23 casos). En cambio, el tipo “centrado generalizado" en el receptor y "centrado generalizado" en una tercera persona no se encuentra en las redacciones aunque sí bastante en el foro y en las conversaciones. Encontramos 0,83 ocurrencias (proporcionalmente) de tipo “vago" en las conversaciones. En cambio, no aparece ninguna ocurrencia en las redacciones académicas ni en el foro de preguntas/respuestas. Por fin, como lo mencionamos en 5.2. Posiciones intermediarias, en el foro, encontramos varios casos (proporcionalmente $2,99)$ que situamos entre el tipo “centrado generalizado” en el hablante y “centrado generalizado" en el receptor. Estos casos parecen relacionar ambos participantes de la situación comunicativa y generalizan la oración entera. En cambio, no encontramos estos casos, que relacionan específicamente estos dos tipos centrados generalizados, en las redacciones y tampoco en las conversaciones. También aparecen varios otros casos intermediarios en el foro y en las conversaciones. En cambio, casi no aparecen en las 
redacciones académicas. La situación comunicativa (que se relaciona al género discursivo) puede contribuir a explicar que no los encontramos en las redacciones. La no interactividad de este género y, además, la ausencia de participantes directos en la situación comunicativa, excepto por el escritor, reduce la necesidad de incluir/combinar varias lecturas del pronombre uno.

A partir de estos resultados, deducimos que el uso de uno varía en función del género discursivo. Efectivamente, en el foro y en las conversaciones, la referencia de uno depende mayoritariamente de los participantes en la situación comunicativa (uso de tipos centrados generalizados y vagos). Además, en varias ocurrencias, la referencia no se puede tipificar de forma precisa. Se observan casos intermediarios entre los tipos que definimos. En cambio, las redacciones académicas se destacan por un lado a nivel cuantitativo por un uso de uno menor en general que en los dos otros géneros y, por otro lado, a nivel cualitativo, por un uso más bien genérico reducido (se trata de la mayoría de los casos) o centrado generalizado en el emisor. Desde luego, se privilegian usos en los cuales los participantes en la situación comunicativa no destacan.

6.3. Análisis cuantitativo de los factores que influyen en la interpretación de uno en los géneros estudiados

El análisis de los factores que influyen en la interpretación del pronombre uno (factores del nivel más amplio que la oración) muestra, como se puede ver en las tablas 5 y 6, en primer lugar que los factores que favorecen una lectura genérica, a saber la presencia de otros mecanismos impersonales o indefinidos y la presencia de un contexto genérico, vago o indefinido, aparecen en la gran mayoría de las ocurrencias (respectivamente en 100 y 115 casos de 139).

Tabla 5. Presencia de otros mecanismos impersonales por género discursivo

Efectivo

\begin{tabular}{|c|c|c|c|c|c|}
\hline & & Redac. acad. & Conv & Foro & \\
\hline Presencia de otros &, 0 & 4 & 5 & 30 & 39 \\
\hline mecanismos impersonales & 1,0 & 7 & 23 & 70 & 100 \\
\hline Total & & 11 & 28 & 100 & 139 \\
\hline
\end{tabular}


Tabla 6. Presencia de contexto genérico por género discursivo

Efectivo

\begin{tabular}{|l|l|l|l|l|l|}
\hline \multicolumn{2}{|c|}{} & Redac. acad. & Conv. & Foro & \\
\hline $\begin{array}{l}\text { Presencia de contexto,0 } \\
\text { genérico }\end{array}$ & 4 & 6 & 14 & 24 \\
\cline { 2 - 7 } & 1,0 & 7 & 22 & 86 & 115 \\
\hline Total & 11 & 28 & 100 & 139 \\
\hline
\end{tabular}

En segundo lugar, constatamos que proporcionalmente, la presencia de otros mecanismos impersonales o indefinidos en el contexto lingüístico de las ocurrencias de uno aparece más en las conversaciones que en las redacciones y el foro. Paralelamente, un contexto genérico, vago o indefinido de uno aparece proporcionalmente más en las conversaciones y en el foro que en las redacciones académicas.

En tercer lugar, observamos que en gran mayoría de las ocurrencias (118 casos en 139 casos totales), encontramos un co-referente en el contexto lingüístico del pronombre uno indefinido.

Tabla 7. Presencia de co-referencia por género discursivo

Efectivo

\begin{tabular}{|l|l|l|l|l|l|}
\hline \multicolumn{2}{|c|}{} & Redac. acad. & Conv. & Foro & \\
\hline \multirow{2}{*}{ Presencia de co-referencia } &, 0 & 2 & 5 & 14 & 21 \\
\cline { 2 - 7 } & 1,0 & 9 & 23 & 86 & 118 \\
\hline Total & 11 & 28 & 100 & 139 \\
\hline
\end{tabular}

La repartición de los casos en los que no tenemos una co-referencia es más o menos igual en cada género discursivo.

Dentro de las ocurrencias en las que el co-referente es un pronombre o un indicio deíctico (o un sintagma nominal equivalente), destaca que en cada género más o menos la mitad corresponde a un deíctico de primera persona del singular. Estos son además los únicos deícticos que encontramos en las redacciones académicas (aunque aparecen 
menos frecuentemente). Estos datos apoyan la hipótesis de la mayor subjetividad en los géneros interaccionales (Scheibman, 2002).

La segunda persona del singular así que la primera persona del plural son también relativamente frecuentes en el foro YCCQA (con respectivamente 27 y 11 ocurrencias). En las conversaciones, encontramos también varias formas de segunda y tercera persona del singular.

Tabla 8. Deíctico por género discursivo

Efectivo

\begin{tabular}{|l|l|l|l|l|l|}
\hline \multicolumn{2}{|c|}{} & Redac. acad. & Conv. & Foro & Total \\
\hline \multirow{5}{*}{ Deíctico } & 0 & 6 & 7 & 12 & 25 \\
\cline { 2 - 7 } & $1-1$ a pers sg & 5 & 14 & 45 & 64 \\
\cline { 2 - 7 } & $2-2$ a pers sg & 0 & 3 & 27 & 30 \\
\cline { 2 - 7 } & $3-3$ a pers sg & 0 & 3 & 4 & 7 \\
\cline { 2 - 7 } & $4-1$ a pers pl & 0 & 0 & 11 & 11 \\
\cline { 2 - 7 } & $5-2$ a pers pl & 0 & 0 & 1 & 1 \\
\cline { 2 - 7 } & $6-3 a$ pers pl & 0 & 28 & 100 & 139 \\
\hline Total & & 11 & & 1 & 1 \\
\hline
\end{tabular}

Observamos, por lo tanto, una diferencia en los factores que reducen la genericidad de uno con respecto a los géneros discursivos estudiados. Si la correferencia se establece en las redacciones académicas con la primera persona del singular, las correferencias en el foro y en las conversaciones se establecen también con otras personas verbales. En cambio, los factores que favorecen una interpretación genérica del pronombre resultan ser los mismos en los distintos géneros discursivos.

\section{Conclusión}

En resumen, tras haber desarrollado un estado de la cuestión detallado de las definiciones del pronombre indefinido uno, prestando una atención especial en su referencia, hemos empezado por verificar la primera hipótesis, a saber si la interpretación del pronombre uno indefinido depende del contexto lingüístico y 
extralingüístico y no es inherente a la forma. A partir del examen detallado del contexto lingüístico y extralingüístico (los participantes en la situación comunicativa y la situación de comunicación en sí mismo), hemos elaborado una tipología de varios tipos de uno indefinido que colocamos en un continuo del polo de referencia completamente genérica a una referencia completamente específica. En efecto, una serie de factores lingüísticos influyen en la interpretación de las ocurrencias de uno indefinido. Algunos de ellos apoyan más bien una lectura genérica del pronombre (un contexto vago, indefinido o genérico y otros mecanismos impersonales o indefinidos del contexto lingüístico). Paralelamente, otros implican una restricción de la referencia (pronombres co-referentes deícticos, sintagmas nominales no deícticos y sintagmas adverbiales temporales o espaciales).

En segundo lugar, hemos podido verificar parcialmente la segunda hipótesis. Hemos estudiado tres corpus de géneros discursivos diferentes: conversaciones informales espontáneas, redacciones académicas de estudiantes y un foro de preguntas y respuestas. Se diferencian desde los puntos de vista "interaccional"/ "no interaccional”, y "mayor presencia de subjetividad/intersubjetividad” y “menor presencia de subjetividad”. Los datos encontrados nos permiten confirmar la hipótesis que la presencia de subjetividad y/o intersubjetividad en el género discursivo y el carácter interaccional del género, y no sólo el registro, influyen en la frecuencia de uno indefinido en el género. Encontramos efectivamente el pronombre en mayor frecuencia en el foro y las conversaciones, que corresponden a las características "mayor presencia de subjetividad/intersubjetividad” e “interactividad”, que en las redacciones académicas, donde su presencia es menos frecuente. Luego, la comparación de los factores estudiados en este artículo en los tres géneros analizados mostró una diferencia notable en cuanto a los factores reduciendo la referencia del pronombre: la reducción se hace en el foro y las conversaciones tanto a partir del hablante como a partir del interlocutor o de una tercera persona. En cambio, la reducción de la referencia se hace únicamente a partir del emisor en las redacciones académicas. Esto se debe al hecho que se trata de un género sin interacción y desde luego con menos presencia del receptor. Al contrario, los factores que favoreces una lectura genérica no aparecen con frecuencias significativamente diferentes en los géneros estudiados. 
Hemos entonces mostrado que el pronombre uno indefinido se interpreta a partir de un contexto lingüístico que va más allá que la oración, además de otros factores del nivel oracional y verbal ya tratados por varios autores.

Si los resultados en cuanto a la segunda hipótesis (si la presencia de uno depende de la subjetividad/ intersubjetividad en el género y de la interactividad del género) son prometedores, una ampliación de la base de datos permitirá responder a esta pregunta de forma más definitiva.

Corpus

CLAE: Corpus de lenguaje académico en español. 2009. http://www.lenguajeacademico.info. UCMexus-CONACYT.

CORLEC: Corpus del Español centro-peninsular, dirigido por Francisco Marcos Marín en la Universidad Autónoma de Madrid con el apoyo de la Agencia Nacional para el Desarrollo de Programas del V Centenario (1990-1993). http://www.lllf.uam.es/ESP/Corlec.html

Yahoo-based Contrastive Corpus of Questions and Answers (YCCQA), compilado por Hendrik De Smet. Departamento de Lingüística, University of Leuven, 2009.

Referencias bibliográficas

Benveniste, Emile, 1966. "De la subjectivité dans le langage.” Problèmes de linguistique générale. Paris: Editions Gallimard, 259-260.

Bello, Andrés y Cuervo, Rufino J., 1964. Gramática de la lengua castellana. $7^{\mathrm{a}}$ ed., Buenos Aires: Sopena.

Biber, Douglas, 1988. Variation across speech and writing. Cambridge: CUP.

Bidot Martínez, Irina, 2008. “La desfocalización del centro deíctico personal a través de la segunda persona del singular” en Boletín de Lingüística, vol XX, núm. 30, 6287.

Brown, Penelope y Stephen C. Levinson, 1987. Politeness: Some universals in language usage. Cambridge: Cambridge University Press. 
Carrasco, Félix, 1980. Actas del VI congreso de la Asociación Internacional de Hispanistas. http://cvc.cervantes.es/literatura/aih/aih_vi.htm

Coussé, Evie y van der Auwera, Johan, 2012. "Human impersonal pronouns in Swedish and Dutch” en Languages in Contrast 12:2, 121-138. http://anet.uantwerpen.be/submit.phtml?UDses=39704084\%3A690507\&UDstate $=1 \& U D$ mode $=\& U D a c c e s s=\& U D r o u=\% 25$ Entry:birwart\&UDextra=a::920.15357 irua

Dahl, Östen, 2000. “Egophoricity in discourse and syntax” Functions of Language 7(1): 37-77.

De Cock, Barbara, 2014 (a). Profiling Discourse Participants. Forms and functions in Spanish conversation and debates, Amsterdam: John Benjamins Publishing Company.

De Cock, Barbara, 2014 (b). "The discursive effects of Spanish uno and se. A case study of the phenomena of speaker inclusion and female-only reference” en Dylan Glynn, Mette Sjölin, Subjectivity and epistemicity. Corpus, discourse and literary approaches to stance, Lund: Lund University Press, 107-120.

De Cock, Barbara (en prensa). "Register and referential ambiguity of personal pronouns : A cross-linguistic analysis”, Pragmatics 26.

De Cock, Barbara (a). "Intersubjective impersonals in context: a multivariate analysis of Spanish uno and se”, $m s$.

DeMello, George, 2000. “Tú impersonal en el habla culta”, en Nueva revista de Filología Hispánica, 48, núm. 2, 359-372.

Fernández Soriano, Olga y Táboas Baylín, Susana, 1999. “Construcciones impersonales no reflejas” en Bosque, Ignacio y Demonte, Violeta (eds.), Gramática descriptiva de la Lengua Española 2, Madrid: Espasa Calpe, 1723-78.

Flores-Ferrán, Nydia, 2009. “Are you referring to me? The variable use of uno and yo in oral discourse.” En Journal of Pragmatics 41(9): 1810-1824.

Gelabert-Desnoyer, Jaime, 2008. "Not so impersonal : intentionality in the use of pronoun uno in contemporary Spanish political discourse” in Pragmatics Vol 18 $n^{\circ} 3,407-427$. 
Givón, Talmy, 1984. Syntax. A Functional-Typological Introduction. Vol 1. Amsterdam: John Benjamins.

Gómez Torrego, Leonardo, 1992. La impersonalidad gramatical: descripción y norma. Madrid: Arco Libros.

González Vergara, Carlos y Hugo Rojas, Evelyn, 2012. ““Cuando te lo piden, uno no siempre sabe qué decir” Uno y tú como estrategias evidenciales en el español de Chile" en Actas del IV Congreso Internacional de Letras "Transformaciones Culturales. Debates de la teoría, la crítica y la lingüística en el Bicentenario", Buenos Aires: Facultad de Filosofía y Letras de la Universidad de Buenos Aires, 647654. https://www.academia.edu/2353794/_Cuando_te_lo_piden_uno_no_siempre_sabe _qu\%C3\%A9_decir_Uno_y_t\%C3\%BA_como_estrategias_evidenciales_en_el_e spa\%C3\%B1ol_de_Chile

Haverkate, Henk, 1985. “La desfocalización referencial.” Hispanic Linguistics 2 (1), 121.

Hernanz, Ma. Lluïsa, 1990. "En torno a los sujetos arbitrarios: La 2a persona del singular” en Violeta Demonte, B. Garza Cuarón (eds.) Estudios de lingüística de España y México, México: Universidad Autónoma de México, 151-178.

Hollaender Jensen, Mikkel, 2002. "La referencia en algunas expresiones impersonales. Diferentes lecturas de uno y la segunda persona del singular”. Romansk Forum 16(2), 127-138.

Kluge, Bettina, "Referential ambiguity in interaction. Establishing generic reference with second person pronouns in the Romance languages", tesis de habilitación (entragada el 20.12.2012).

Kluge, Bettina, 2010. "El uso de formas de tratamiento en las estrategias de generalización”en Formas y fórmulas de tratamiento en el mundo hispánico, Hummel, Martin, Kluge, Bettina y Vázquez Laslop, María Eugenia (eds), México D.F.: El Colegio de México / Karl-Franzens-Universität Graz, 1107-1136. 
Koch, Peter \& Oesterreicher, Wulf, 1985. "Sprache der Nähe - Sprache der Distanz. Mündlichkeit und Schriftlichkeit im Spannungsfeld von Sprachtheorie und Sprachgeschichte.“ Romanistisches Jahrbuch 36: 15-43.

Lavandera, Beatriz, 1984. “Tensión entre lo impersonal y lo personal en la organización del discurso.” En Lavandera, Beatriz (ed.) Variación y significado. Paris: Hachette, 101-124.

Locher, Miriam A., 2013. “Internet advice” en Herring, Susan, Stein, Dieter y Virtanen, Tuija (eds.) Pragmatics of computer-mediated communication. Berlin: De Gruyter Mouton, 339-362.

Lyons, John, 1982. “Deixis and subjectivity: Loquor ergo sum?” en Jarvella, Robert J y Klein, Wolfgang (eds.) Speech, Place and Action New York: Wiley, 101-124.

Martínez, José, 1989. El pronombre II. Numerales, indefinidos y Relativos. Madrid: Arcos Libros SA.

Placencia, María Elena, 2012. “Online peer-to-peer advice in Spanish Yahoo!Respuestas” en Limberg, Holger y Locher, Miriam, Advice in discourse. Amsterdam/Philadelphia: John Benjamins, 281-305.

Pozas Loyo, Julia, 2010. The Development of the Indefinite Article in Medieval and Golden-Age Spanish, Tesis de doctorado, University of London. https://qmro.qmul.ac.uk/xmlui/bitstream/handle/123456789/610/POZAS-

LOYODevelopment2010.pdf?sequence=1

Rasson, Marie, 2012. Los atenuantes en el lenguaje juvenil madrileño, Tesina de Master, Louvain-la-Neuve : Faculté de philosophie, arts et lettres.

Real Academia Española, 2009. Nueva gramática de la lengua española, Madrid: Espasa Libros.

Ridruejo, Emilio, 1981. ““uno” en construcciones genéricas”, Revista de Filología Española, vol. LXI n¹/4.

Rodríguez Alfano, Lidia, 2004. ¿Qué opinas con verbos y pronombres? Análisis del discurso de dos grupos sociales de Monterrey, Monterrey: Facultad de Filosofía y Letras, Universidad Autónoma de Nuevo León. 
Scheibman, Joanne, 2002. Point of view and grammar: Structural patterns of subjectivity in American English conversation. Amsterdam: John Benjamins.

Scheibman, Joanne, 2007. "Subjective and intersubjective uses of generalizations in English conversations” en Englebretson, Robert (ed) Stancetaking in Discourse. Subjectivity, evaluation, interaction., Amsterdam: John Benjamins, 111-138.

Schroten, Jan, 1972. Concerning the Deep Structures of Spanish Reflexive Sentences, The Hague: Mouton.

Schroten, Jan, 2011. “Oraciones impersonales con sujeto humano y su identidad” en Escandell Vidal, Victoria, Leoneti, Manual et al (eds) 60 Problemas de Gramática, Madrid: Akal.

Siewierska, Anna, 2011. “Overlap and complementarity in reference impersonals. Manconstructions vs. third person plural-impersonals in the languages of Europe.” en Malchukov, Andrej y Siewierska, Anna (eds.) Impersonal Constructions. A crosslinguistic perspective. Amsterdam: John Benjamins, 57-89.

Siewierska, Anna y Papastathi, Maria, 2011. “Towards a typology of third person plurals” en Linguistics 49 (3), 575-610.

Traugott, Elizabeth Closs, 2003. "From subjectification to intersubjectification” en Hickey, Raymond (ed.), Motives for Language Change. Cambridge: Cambridge University Press, 124-139.

Van der Auwera, Johan, Gast, Volker y Vanderbiesen, Jeroen, 2012. "Human impersonal pronoun uses in English, Dutch and German” en Leuvense Bijdragen 98, 27-64.

Recibido: 15 de septiembre de 2015

Aceptado: 2 de julio de 2016

Publicado: 23 de septiembre de 2016 